\title{
Tectonic features associated with the overriding of an accretionary wedge on top of a rifted continental margin: An example from Taiwan
}

\author{
Andrew T. Lin ${ }^{\mathrm{a}, *}$, Char-Shine Liu ${ }^{\mathrm{b}}$, Che-Chuan Lin ${ }^{\mathrm{a}}$, Philippe Schnurle ${ }^{\mathrm{b}}$, Guan-Yu Chen ${ }^{\mathrm{a}}$, Wei-Zhi Liao ${ }^{\mathrm{a}}$, \\ Louis S. Teng ${ }^{\mathrm{c}}$, Hui-Ju Chuang ${ }^{\mathrm{b}}$, Ming-Shyan $\mathrm{Wu}^{\mathrm{a}, \mathrm{d}}$ \\ a Institute of Geophysics, National Central University, Taiwan \\ b Institute of Oceanography, National Taiwan University, Taiwan \\ c Institute of Geosciences, National Taiwan University, Taiwan \\ d CPC Corporation, Taiwan
}

\section{A R T I C L E I N F O}

\section{Article history:}

Received 19 March 2008

Received in revised form 26 September 2008 Accepted 3 October 2008

\section{Keywords:}

tectonic inheritance

structural styles

rifted continental margin

accretionary wedge

Taiwan

\begin{abstract}
A B S T R A C T
Off southwest Taiwan, a west-advancing orogenic wedge has obliquely impinged on the northern continental slope of the South China Sea (SCS) margin. We analyzed a dense grid of multi-channel seismic profiles to reveal the tectonic features in this oblique collision setting. In the upper SCS slope and adjacent to the accretionary wedge, the rifted continental margin is characterized by a deep-seated, oceanward-dipping, listric and active normal fault with rotated hangingwall strata beneath the slope. To the west of this slope segment, the mid-Oligocene to Recent post-breakup sediments show prograding and aggrading shelf-margin clinoforms that cover a series of small, possibly Paleogene, rift basins.

In the submarine accretionary wedge, a series of west-vergent, NNW-striking fold-and-thrust structures characterizes the lower wedge, which can be further divided into frontal and rear segments with distinct structural features. The frontal segment is characterized by four west-vergent blind thrusts with gently folded limbs. In contrast, the rear, arcward segment is characterized by west-vergent, emergent and imbricate thrusts with tilted beds truncated at the hangingwalls. Strata within slope basins are tilted arcward, with dips that increase with depth, indicating continued relative uplift along thrust planes during sedimentation. Pulsed thrust activity is further evidenced by an array of arcward-dipping unconformable surfaces with westward onlapping strata in the basins.

Longitudinal sedimentary tapering of pre-orogenic sediments correlates strongly with curvature of the submarine frontal accretionary belt, suggesting that pre-orogenic sediment thickness is the major control on the geometry of frontal structures. The preexisting SCS slope that lies obliquely in front of the advancing accretionary wedge has impeded the advancing of frontal folds resulting in a successive termination of folds against and along strike of the SCS slope. The existence of the SCS slope also leads the strike of impinging folds with NNW-trend to turn more sharply to a NE-strike, parallel to strike of the SCS slope. Our analysis shows that the pre-orogenic mechanical/crustal heterogeneities and seafloor morphology exert strong controls on the thrust-belt development in the incipient Taiwan arc-continent collision zone.
\end{abstract}

(c) 2008 Elsevier B.V. All rights reserved.

\section{Introduction}

The region off SW Taiwan (Fig. 1) lies in the frontal zone of initial oblique collision between the China continent and the Luzon arc (e.g., Huang et al., 1997; Lacombe et al., 2001) where the South China Sea basin closes and the submarine accretionary wedge emerges to form subaerial collisional orogenic wedges (i.e., the Taiwan orogen). The close proximity of the rifted continental margin to the collisional wedge provides us with a rare opportunity to address the geometric

\footnotetext{
* Corresponding author. Department of Earth Sciences, National Central University, 320 No.300 Chungda Road, Chungli, Taoyuan, Taiwan. Tel.: +8863 4262782; fax: +88634222044. E-mail address: andrewl@ncu.edu.tw (A.T. Lin).
}

and kinematic processes operating in the accretion of passive margin rocks into an accretionary wedge and the controls of rifted-margin crustal inhomogeneity and seafloor relief on subsequent development of the frontal orogenic wedge.

Various geological features of the orogenic wedge and rifted continental margin (i.e., the Tainan Basin) off SW Taiwan have been reported in the literature. For examples, Reed et al. (1992), Sun and Liu (1993), and Liu et al. (1997, 2004) have demonstrated the compressive structures in the accretionary wedge. Yang et al. (1991), Lee et al. (1993), Lin and Watts (2002), Lin et al. (2003) and Li et al. (2007) have reported the stratigraphy and tectonic features of the Tainan Basin, which lies in the rifted continental margin. In spite of all these previous efforts, aspects of the structural styles of the accretionary 


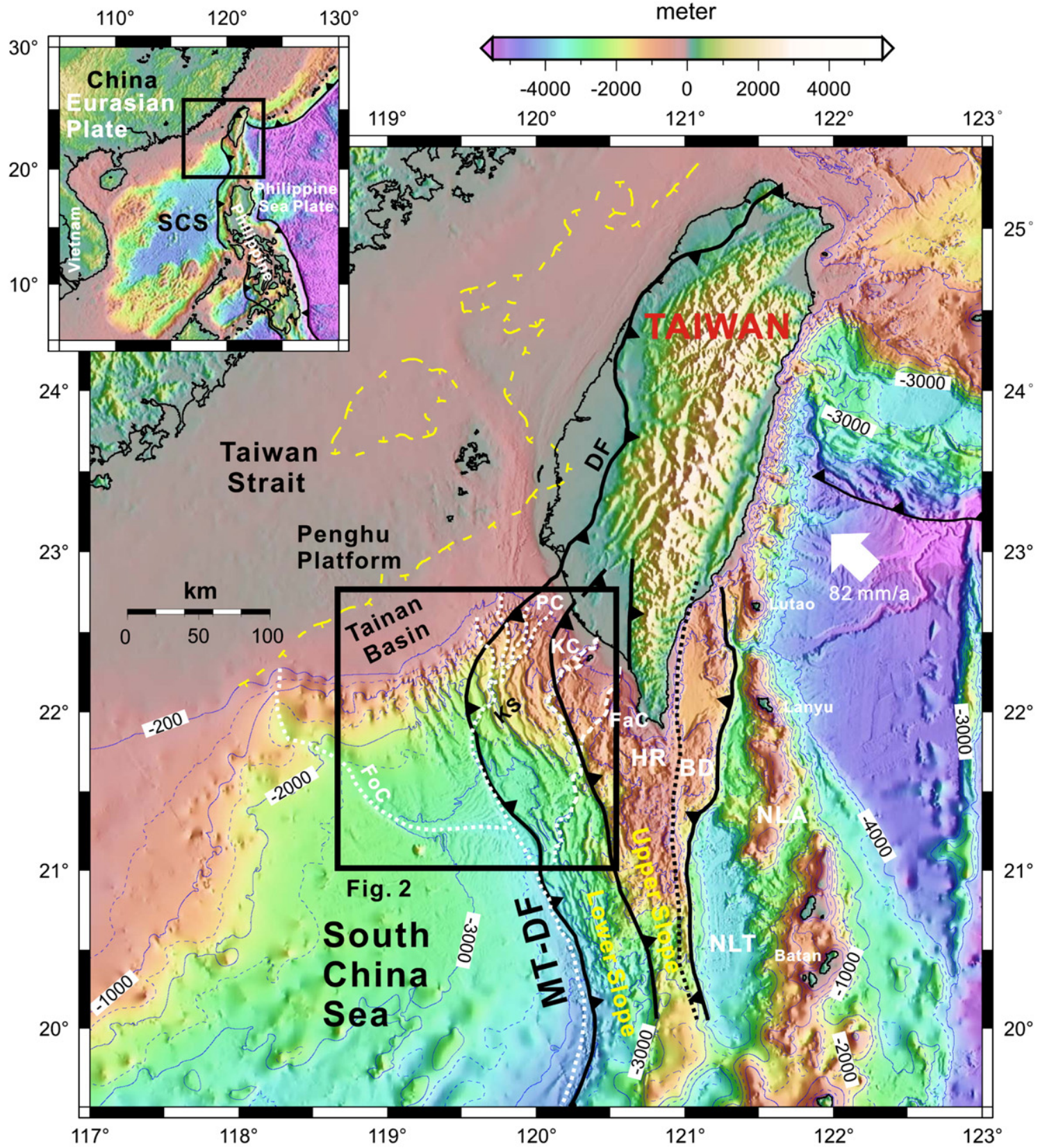

BD=Backthrust domain; DF=Deformation Front; FaC=Fangliao Canyon; FoC=Formosa Canyon; $\mathbf{H R}=$ Hengchun Ridge; $\mathbf{K C}=$ Kaoping Canyon; $\mathbf{K S}=$ Kaoping Slope; $\mathbf{M T}=$ Manila Trench; $\mathbf{N L A}=$ North Luzon Arc; NLT=North Luzon Trough; PC=Penghu Canyon

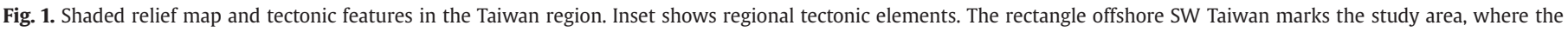

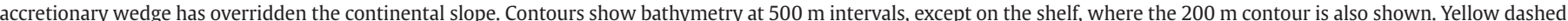

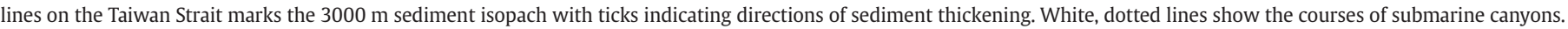
Abbreviations are listed at the bottom. The white arrow labeled with a number shows the direction and rate of plate motion after Yu et al. (1997).

wedge and the rifted margin and especially their interrelations remain unclear.

The Central Geological Survey of Taiwan has initiated geophysical/geological studies off SW Taiwan since 2004 in a bid to explore gas-hydrate potential. As a part of this program multichannel seismic (MCS) reflection profiles up to 9500 line-km and of $\sim 1.85 \mathrm{~km}$ in line spacing were collected and processed. We analyzed this MCS dataset along with high-resolution seafloor imagery in an attempt to reveal the detailed geological structures in this tectonically critical area.
In this paper, we present the results of our analyses by illustrating the structural styles of the rifted continental margin and the lower, frontal accretionary wedge. The high resolution of structural details achieved in this dataset, for the first time, allows us to discuss the evolution of structural styles across the lower accretionary wedge, an issue that has been largely untouched in previous studies. We then discuss the architecture of the rifted continental margin and preexisting seafloor relief and their possible controls on the subsequent development of the overriding orogenic wedge. An important finding from our study is the recognition that thickness 
of the pre-orogenic sediments plays an important role in determining the map-view geometry of the deformation front.

\section{Geological framework and seafloor morphology}

Offshore southern Taiwan, prominent morphological features are a series of north-south-trending ridges and troughs, including North Luzon Arc, North Luzon Trough, Hengchun Ridge, and Manila Trench (Liu et al., 1998, Fig. 1). Farther north, the Luzon arc-trench system connects to the Taiwan orogen. This arc-trench system can be well perceived in the area south of $\sim 21^{\circ} 30^{\prime} \mathrm{N}$ (Liu et al., 1997). North of $\sim 21^{\circ} 30^{\prime} \mathrm{N}$, the Manila trench loses its morphological characteristics and is replaced by the deformation front (barbed black line shown in Fig. 1) of the Taiwan region. West of the Manila trench and deformation front lies the northern corner of the South China Sea (SCS) basin and the $\mathrm{N} 60^{\circ} \mathrm{E}-$ trending rifted continental margin, which, however, switches to $\mathrm{N} 30^{\circ} \mathrm{E}-$ trending southwest of the Formosa canyon (FoC in Fig. 1).

The accretionary wedge rises up to $3000 \mathrm{~m}$ in height from the deformation front at latitude of the southern tip of the Taiwan island. Three major canyon systems, namely Penghu (Yu and Chang, 2002), Kaoping (Liu et al., 1993; Chiang and Yu, 2006), and Fangliao (Yu and Lu, 1995) canyons, cut across the western part of the wedge, draining sediments from the uplifting Taiwan orogen. The wedge is marked in front by a stack of west-vergent fold-and-thrust structures (Liu et al., 1997) and in rear by a backthrust system (or domain) that assists in the closure of the forearc basin (i.e., the North Luzon Trough, shown in Fig. 1, Lundberg et al., 1997).

\subsection{Submarine accretionary wedge}

Reed et al. (1992) divided the accretionary wedge into three structural domains, from the west to the east, the lower slope, upper slope and backthrust domains (Fig. 1). They put the boundary between the lower and upper slope on the eastern bank of the NNE-trending Kaoping canyon (note that the Kaoping canyon is their northern limit of this inferred boundary). On the basis of our newly collected seismic reflection data, we are able to connect this boundary to R8.1 structure (see later) to the north of the Kaoping canyon and a diapiric structure along strike and farther north (Figs. 2 and 3). It then merges with the onshore Shoushan fault (Chen et al., 2001).

The lower-slope domain consists of north- to northwest-trending, mostly west-vergent ramp anticlines spaced between 5 and $10 \mathrm{~km}$ (Reed et al., 1992; Liu et al., 1997). The decollement typically lies 0.1$0.3 \mathrm{~s}$ above rifted blocks of the China continental margin and oceanic crust of the South China Sea (Reed et al., 1992). Seismic reflections in the upper-slope domain, however, are highly discontinuous and low amplitude, suggesting steeply-dipping or intense deformation of accreted strata (Reed et al., 1992). Close to Taiwan, the western half of the upper-slope domain is characterized by a series of mud diapiric structures with intervening basins showing thick and doubly wedging basin sequences (Sun and Liu, 1993; Chiang et al., 2004). Arcward, the eastern half of the upper-slope domain is manifested as the southern tip of the Taiwan island with exposed Miocene strata stacked in multiple thrust slices (Sung, 1991; Chang et al., 2003).

\subsection{Rifted continental margin}

The northern margin of the SCS (including the Taiwan Strait, Fig. 1) is a part of rifted continental crust with a series of rift basins related to Paleogene rifting of the South China continent (Lin et al., 2003). Near the Taiwan orogen, the rifted continental crust has been flexed downward by orogenic loading, and has formed a foreland basin since $\sim 6.5 \mathrm{Ma}$ (Lin and Watts, 2002). Part of the superposed rift basin and foreland basin, lying at the outer margin both in the shelf and slope areas (i.e., the Tainan basin, Fig. 1), has been incorporated into the collisional fold-and-thrust belt (Lin et al., 2003).
The Tainan basin is bounded to its north by a series of normal faults, the Yichu fault zone (Yang et al., 1991), which lies approximately along the 3000-m sediment isopachs (shown as dashed yellow lines in Fig. 1). Three tectonic domains, namely the Northern Depression, the Central Uplift Zone, and the Southern Depression characterize the Tainan basin (Tsao et al., 1992). The Northern Depression and Central Uplift Zone lie beneath the shelf region and the Southern Depression lies beneath the slope region. In the shelf region, there have been great efforts in hydrocarbon exploration since the 1970s, resulting in a large amount of seismic data as well as 45 exploration wells with one gas field discovery, the F-Field (Fig. 2). Because the industrial data covers mainly the shelf region, past studies tend to focus on the Northern Depression and Central Uplift Zone beneath the shelf (e.g., Yang et al., 1991; Lee et al., 1993; Tzeng et al., 1996; Tang et al., 1999; Lin et al., 2003). The Southern Depression, in the deeper-water area, has remained relatively unexplored.

\section{Data}

Multichannel seismic reflection (MCS) and bathymetric data are used in this study to determine the subsurface geological structures. A total of 6 grids of seismic data (MCS647, 681, 716, 719, 754, 764, see Fig. 2) with a total line length of more than $9500 \mathrm{~km}$ covering an area of $\sim 11,000 \mathrm{~km}^{2}$ were collected onboard R/V Ocean Researcher I (ORI) during 2002-2005. The seismic data cover both the orogenic wedge and the South China Sea continental slope (Fig. 2) and were collected with different seismic acquisition parameters by various ship cruises of ORI. For grids of MCS647 and MCS681, the data were collected using 48 channels with 12.5 -m channel spacing, 587.5-m-long streamer, and shots were fired at 10 second intervals using an air-gun array of $475 \mathrm{cu}$. in. in total volume, which was towed at a depth of $5 \mathrm{~m}$. With an averaged ship speed of 4.86 knots, the shot interval is of $25.3 \mathrm{~m}$, yielding a $\sim 12$-fold common mid point coverage. The recorded trace length was $5 \mathrm{~s}$ with a sampling rate of $2 \mathrm{~ms}$. Other grids of seismic data employed in this study were acquired with similar acquisition parameters except that the number of channels was 24 , and the airgun capacity ranged from 425 to $775 \mathrm{cu}$. in. This receiver-source configuration leads to a $\sim 6$-fold common mid-point coverage. The majority of the seismic lines were shot with a spacing of about 1 arcminute equivalent to $1.86 \mathrm{~km}$.

All the MCS data employed in this study were processed at the Institute of Oceanography, National Taiwan University as described in Liu et al. (2006). A typical processing sequence applied to our seismic data set includes trace editing, spiking noise removal, water column mute, geometry set up, amplitude compensation, predictive deconvolution, band-pass filtering, velocity analysis (only for seismic grids of MCS647 and MCS681), normal move-out correction, stacking, and constant velocity $\left(1500 \mathrm{~ms}^{-1}\right) \mathrm{F}-\mathrm{K}$ time migration.

Also used in this study were the large-offset seismic reflection data of EW9509 (see Fig. 11, for example) collected by the R/V Maurice Ewing using a seismic source of 20-gun array with a total volume of $8420 \mathrm{cu}$. in., a 160-channel streamer in 1995, and a source-receiver configuration yielding a $\sim 37$-fold common mid point coverage. This data set provides a better image for deeper structures and stratigraphy in the study area. Part of the EW9509 seismic lines used in this study have been published (for examples, Sibuet et al., 2002).

Although our newly collected MCS data covers most of the slope area, the data only provide good subsurface imaging shallower than about $2 \mathrm{~km}$ beneath the seafloor because of limited air-gun capacities; therefore, deeper basement structures are usually not resolvable. Nonetheless, a few published deep reflection seismic profiles (see Fig. 2 for locations) provide good imaging for deeper basement structures beneath the SCS slope. They are the EW9509 lines (e.g., Sibuet et al., 2002), 973G profile collected onboard R/V Tanbao in 2002 and shown both by Yan et al. (2006) and Li et al. (2007), and 3117 line. Among these, a line drawing interpretation of EW9509-34 profile is 


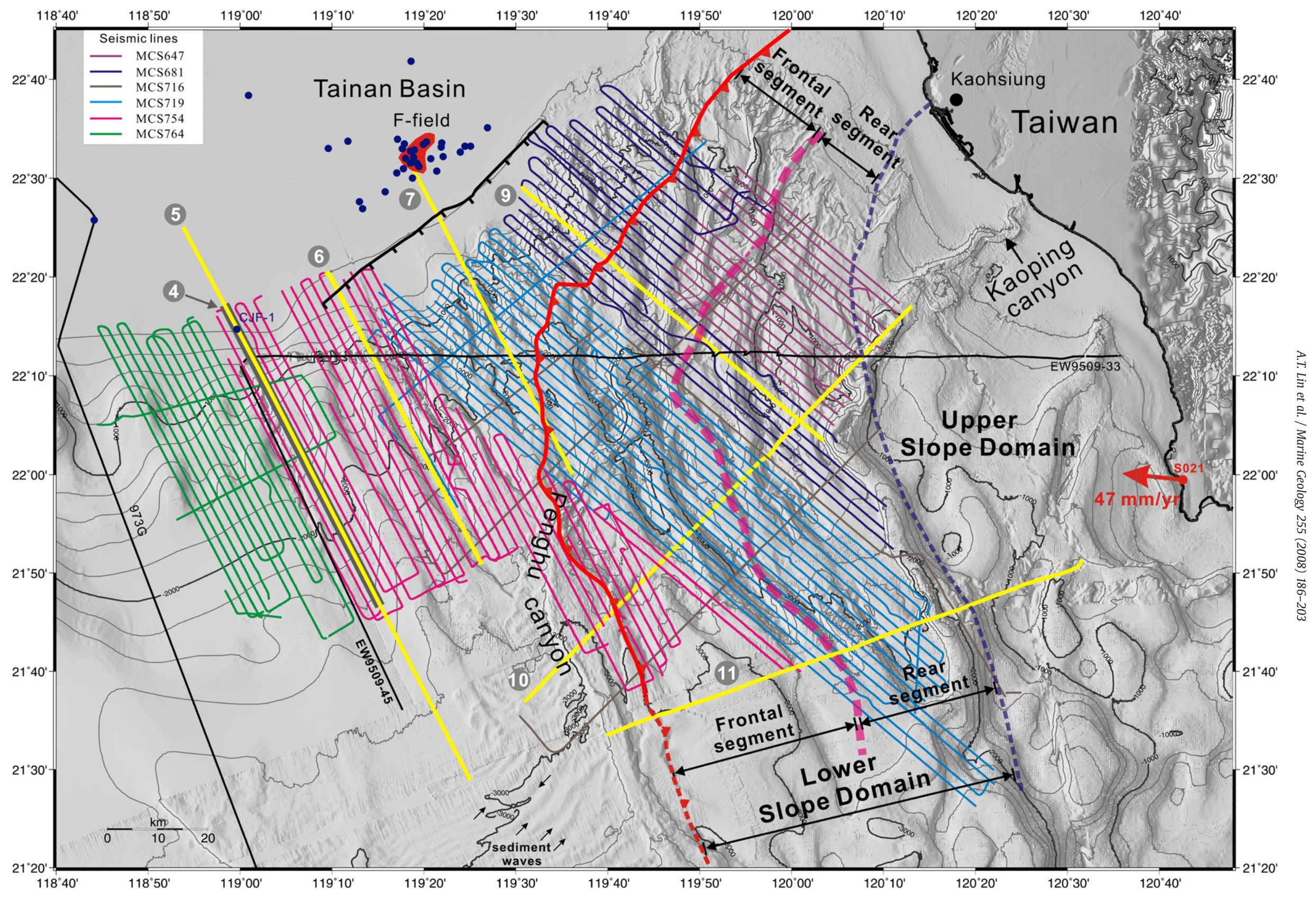

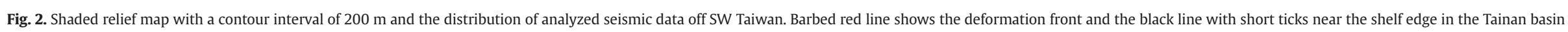

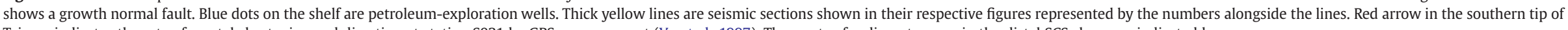
Taiwan indicates the rate of crustal shortening and direction at station S021 by GPS measurement (Yu et al., 1997). The crests of sediment waves in the distal SCS slope are indicated by arrows. 


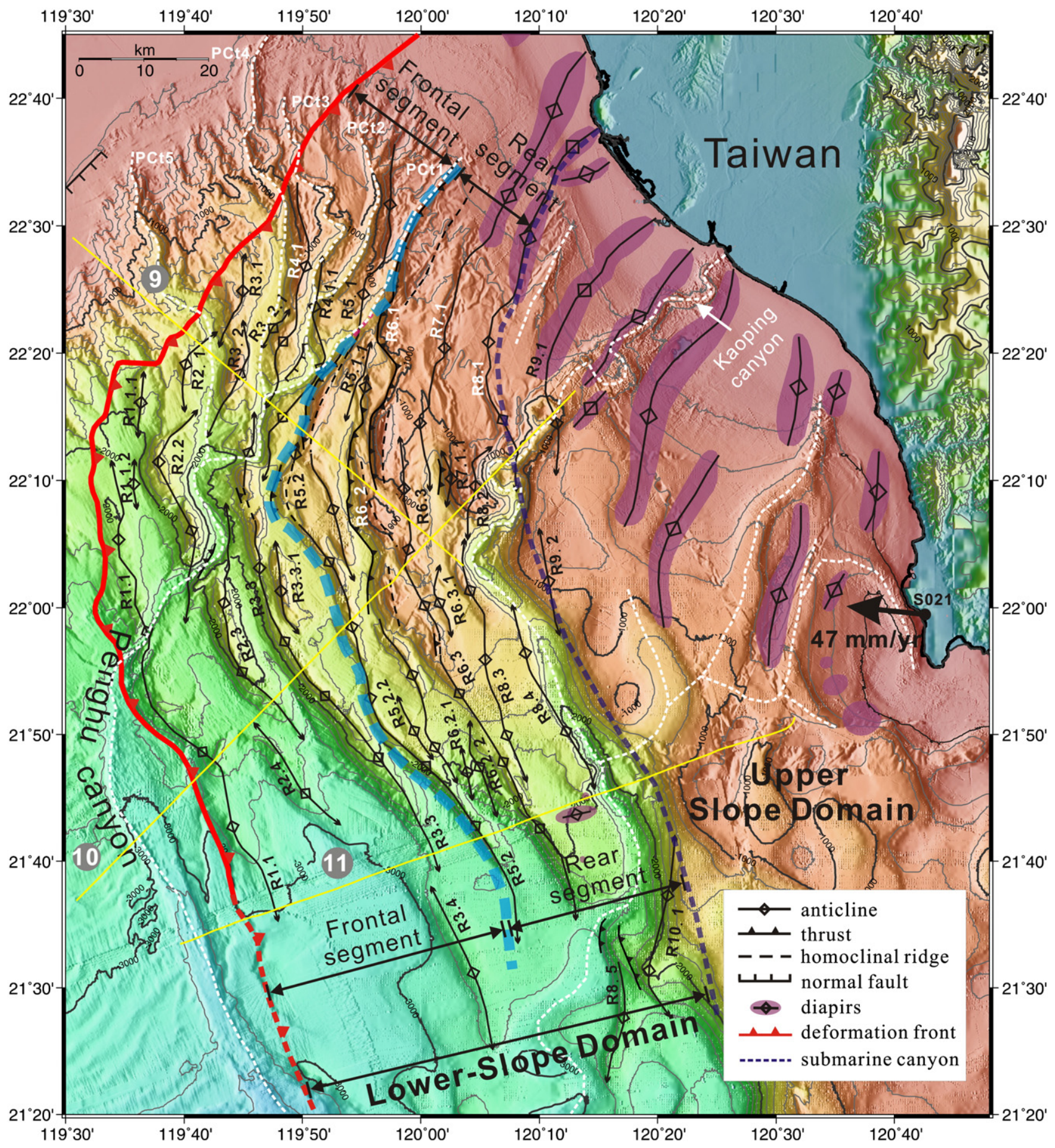

Fig. 3. Shaded relief map off SW Taiwan showing structures in the lower and upper slope domains of the accretionary wedge. Note that the upper slope is dominated by anticlinal features accompanied by mud diapirism, and the lower slope is dominated by emergent thrusts (barbed line) in the rear segment and anticlines cored by blind thrusts in the frontal segment. The name (e.g., R5.2) alongside each structure line is given for indexing the structures mentioned in the text. Dashed white lines denote canyon courses. PCt1-5 are tributaries of the Penghu canyon. Numbers inside circles refer to figure numbers that show seismic sections denoted by yellow lines. Black arrow onshore Taiwan indicates the rate of crustal shortening and direction at station S021 by GPS measurement (Yu et al., 1997). Contour interval is $200 \mathrm{~m}$.

shown in Fig. 5 and the seismic image of 3117 is shown in Fig. 7 along with line drawing interpretations.

For seismic line EW9509-34, we extended its coverage to the upper slope and shelf regions utilizing seismic profiles of 81-1F-61 drawn from Tang et al. (1999) and MCS754-40 in order to establish a slopeperpendicular, 8-km deep crustal section as shown in Fig. 5. We used a sediment velocity function shown by Chen (2006) for CJF-1 well for converting seismic travel time into depth.

The bathymetric data were published by Liu et al. (1998, 2004), which provides a good coverage of the study area with a spatial resolution around $0.1-1 \mathrm{~km}$. Most of the bathymetric data are from swath bathymetry as shown in Liu et al. (2004).

\section{Tectonic features in the South China Sea slope (Tainan Slope)}

Perhaps the most striking tectonic feature for the SCS slope in the Tainan basin (hereafter named Tainan slope) is that the eastern half of this segment has been partly incorporated into the frontal accretionary wedge as seen from Fig. 2. The eastern half features a steeper slope (about $4^{\circ}-5^{\circ}$ ) than its western counterpart (i.e., the western half, 


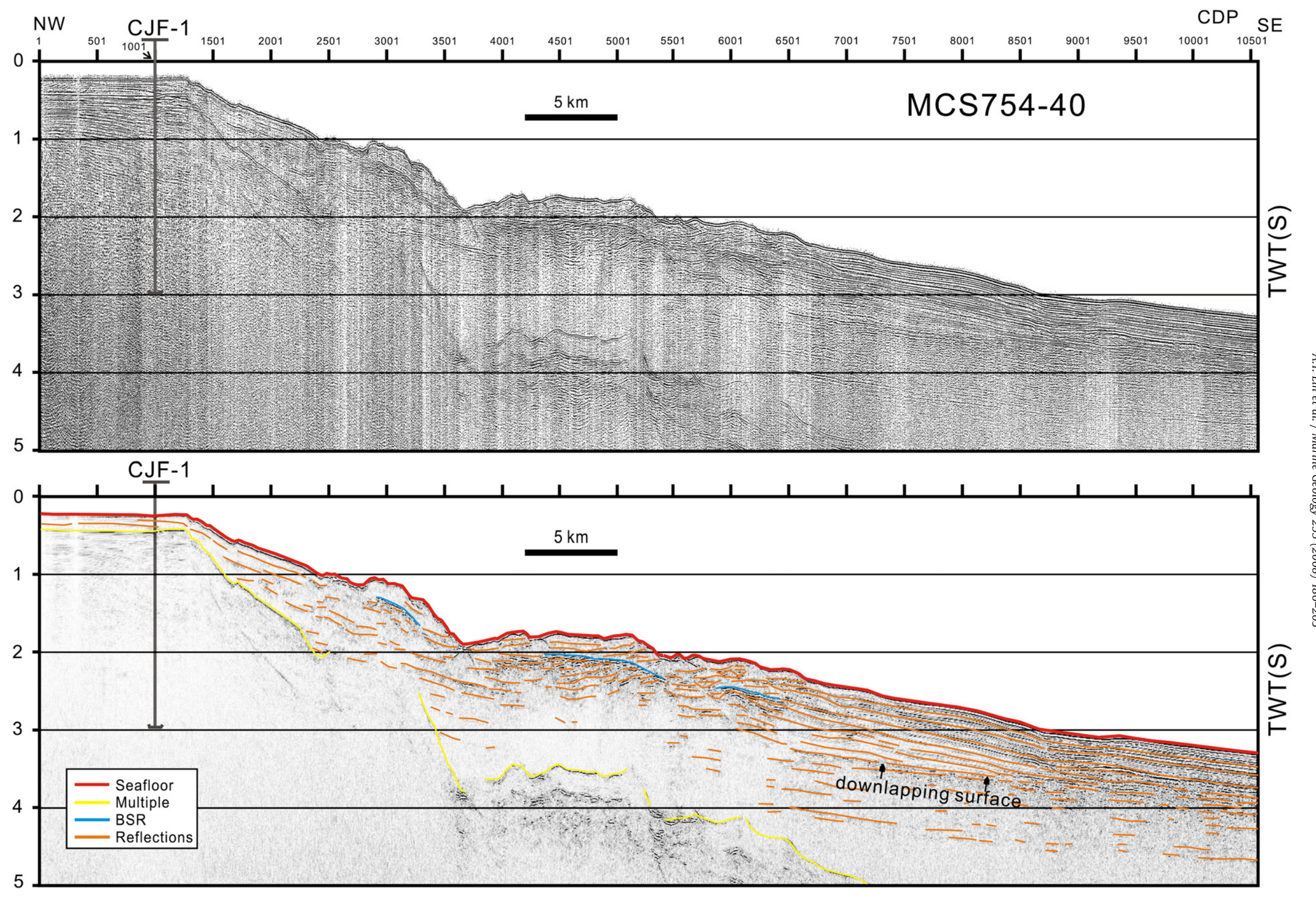

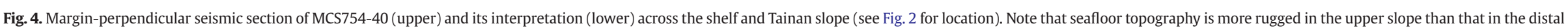

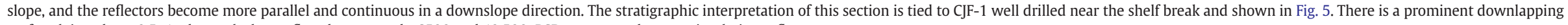
surface lying about $0.5-1 \mathrm{~s}$ beneath the seafloor between cdp 6500 and 10,500. BSR represents bottom simulating reflectors. 
about $2^{\circ}-3^{\circ}$ ), which exhibits a slope profile with prograding as well as aggrading sedimentary packages with local erosion, similar to other passive continental margins worldwide (e.g., Bartek et al., 1991).

\subsection{Western half of the Tainan slope}

The western and upper continental slope is a zone of rugged topography with truncations of reflectors beneath local steep slopes (Fig. 4). The truncations are more evident on profiles running across slope-perpendicular ridges and gullies (not shown in this paper), suggesting that the ridges are remnant features due to erosion probably related to sediment gravity flows. In contrast, the lower continental-slope region is a zone of subdued topography with seismic reflectors conformable to seafloor relief, indicating deposition rather than erosion in this region (Fig. 4). A few shallowly penetrated normal faults are observed on seismic profiles, especially in the upper continental slope. Individual normal faults are limited in areal extent and generally can not be traced to adjacent seismic profile spaced at $\sim 1.86 \mathrm{~km}$ apart. In vertical sections, these normal faults do not seem to cut through sediments deeper than $1 \mathrm{~s}$ beneath the seafloor but sole out at shallow depth, which indicates that the normal faults are local features and they may be caused by gravitational sliding. An alternative explanation for these normal faults is that they are a network of polygonal faults developed in response to dewatering of fine-grained sediments (e.g., Cartwright and Lonergan, 1996), similar to those reported in many other continental slopes (e.g., Cartwright and Dewhurst, 1998).

Fig. 5 serves as an example for the stratigraphic architecture in the western half of the Tainan slope. It shows that, beneath the continental slope, a series of small rift structures possibly Paleogene in age (see later) are buried by $\sim 3-4 \mathrm{~km}$ thick Oligocene and younger sediments with a thick body of volcanic rocks sitting on top of the breakup unconformity (BU) beneath the distal slope. Strata of the Paleogene rift structures are bounded by the rift-onset unconformity (ROU) below and breakup unconformity above, related to the rifting and breaking up of the South China continental crust in the sense of Lin et al. (2003). The Cenozoic sediment thickness, around $4 \mathrm{~km}$, beneath the slope is consistent with the estimates of Lin et al. (2003).

The line drawing interpretation of seismic profile 81-1F-61 (Tang et al., 1999) beneath the shelf is shown in Fig. 5. Near the shelf edge, a borehole, CJF-1, $3848 \mathrm{~m}$ in depth penetrated through the midOligocene-Recent sequence into the Lower Cretaceous sedimentary rocks (Tzeng et al., 1996; Tang et al., 1999) with Paleogene syn-rift sediments missing. The stratigraphic sequence of CJF-1 may serve as a typical sedimentary succession for the Northern Depression and the Central Uplift Zone of the Tainan basin beneath the shelf. The Oligocene sediments are mostly shallow-marine sandstones (Lee et al., 1991) deposited in the subsiding outer continental margin during a long-term relative sea-level rise in the early phase of the seafloor spreading of the South China Sea. It is therefore coined "Oligocene Transgressive Sandstone" (e.g., Tsao and Chang, 1988) and regarded as the main reservoir interval for the Tainan basin. The "Oligocene Transgressive Sandstone" lies unconformably on top of Lower Cretaceous siliciclastic strata of continental facies and underlies a thick succession of Miocene to Recent shallow marine mudstones and sandstones (Lee et al., 1991). Seismic data show that the sediments beneath the shelf are block faulted (Fig. 5) and the normal faulting is probably related to two post-breakup extensional events during 30-21 Ma (mid-Oligocene to early Miocene) and $~ 12.5-$ 6.5 Ma (late Miocene) (Lin et al., 2003). Shelf-margin clinoforms are also evident in the Pliocene-Pleistocene succession (Fig. 5), with the lower succession exhibiting progradation and aggradation while the upper succession shows aggradation. The horizon that separates the lower predominantly prograding and upper aggrading units is a downlapping surface (a maximum marine-flooding surface) about $1 \mathrm{~s}$ beneath the slope (Fig. 4). Beneath the downlapping surface, the sediment thickness is fairly constant and the reflections are weak and discontinuous without faulting. In contrast, sediments above the downlapping surface thin toward the lower slope and show relatively strong and continuous reflections. On some seismic sections, active but not well-developed and upslope-migrating sediment waves, as reported in Wynn and Stow (2002) are present in the lower continental slope in water depths greater than $\sim 2000 \mathrm{~m}$. The sediment-wave fields in the distal slope are more evident in mapview, especially at water depths around $3000 \mathrm{~m}$ (Fig. 2).

A few small fault-bounded half-grabens or grabens beneath the continental slope are interpreted from deep seismic profiles, between the acoustic basement and shelf margin clinoforms (Fig. 5). Although there is no direct age dating for these fault-bounded sediments, a correlation between the shelf and slope reflectors tied to the stratigraphy encountered at CJF-1 well allows us to infer that the fault-bounded basins are most likely filled with Oligocene and older (e.g. Eocene) sediments and floored by Mesozoic sedimentary rocks. In addition, Yan et al. (2006) and Li et al. (2007) presented an MCS profile, 973G, to the west of our study area (see Fig. 2 for location). The profile also shows a similar fault-bounded half-graben.

\subsection{Eastern half of the Tainan slope}

In the eastern half of the Tainan slope, an active normal fault of $\sim 60 \mathrm{~km}$ in length develops near the shelf edge (Fig. 2). The hangingwall of the normal fault rotates in a shelfward direction, and some of the tilted beds are truncated beneath the seafloor near the shelf edge (Figs. 6 and 7). In the upper continental slope, erosional gullies and remnant ridges are clearly shown by truncations of reflectors beneath the seafloor on the left side of the ridge (Fig. 6). The distal slope shows, however, subdued seafloor topography with reflectors parallel to the seafloor, indicating sediment deposition rather than erosion. The recent sedimentary processes in this part of the slope are similar to those of its western counterpart marked by an eroding upper slope and depositional lower slope.

Close to Taiwan, the thickness of post-breakup sediment beneath the slope is at least $3 \mathrm{~s}$, but the breakup unconformity and Mesozoic basement are not shown beneath the slope owing to deeper burial (Fig. 7). The shelf-edge and shelf-edge-parallel active normal fault are clearly seen on this profile with a $\sim 60 \mathrm{~m}$ high seafloor fault scarp and rotated hangingwall strata. The fault and fault scarp can be traced to other deep seismic profiles (see Fig. 8 of Lin et al. (2003), for an example). Using these deep seismic profiles we are able to map out the lateral extent of this fault as shown in Fig. 2. Whether this normal fault cuts into the Mesozoic basement or soles out in the Cenozoic cover sediments is unclear at this seismic line. Nearby seismic profiles (e.g., Fig. 8 of Lin et al., 2003), however, show that this normal fault does not cut into the Mesozoic basement but soles out near the base of the Cenozoic sediment cover at a depth around $4 \mathrm{~s}$ near the shelf break. Beneath the deeper slope at around $\sim 1.8 \mathrm{~s}$ in water depth is a gentle fold that we infer to result from decollement folding related to the detachment of the active normal fault. The normal fault may well flatten near $\sim 4-5 \mathrm{~s}$, become bedding parallel, and reach the base of the gentle fold beneath the slope as shown in Fig. 7. These features indicate that the normal fault is gravity-driven, with abrupt shelf-edge relief providing gravity potential sufficiently large to induce slip and a resulting toe thrust accommodating downdip translation. Similar features either in large or small scales have been reported from other passive continental margins around the world (e.g., Rowan et al., 2004; Corredor et al., 2005). Finally, Fig. 7 shows that, in the distal slope, the accretionary wedge impinges on the slope at about $2200 \mathrm{~m}$ water depth with gently deformed frontal structure (R1.1 fold). The frontal structure is not clear on Fig. 7 but it becomes clearer when traced from surrounding area (see Figs. 3 and 10, for examples). 


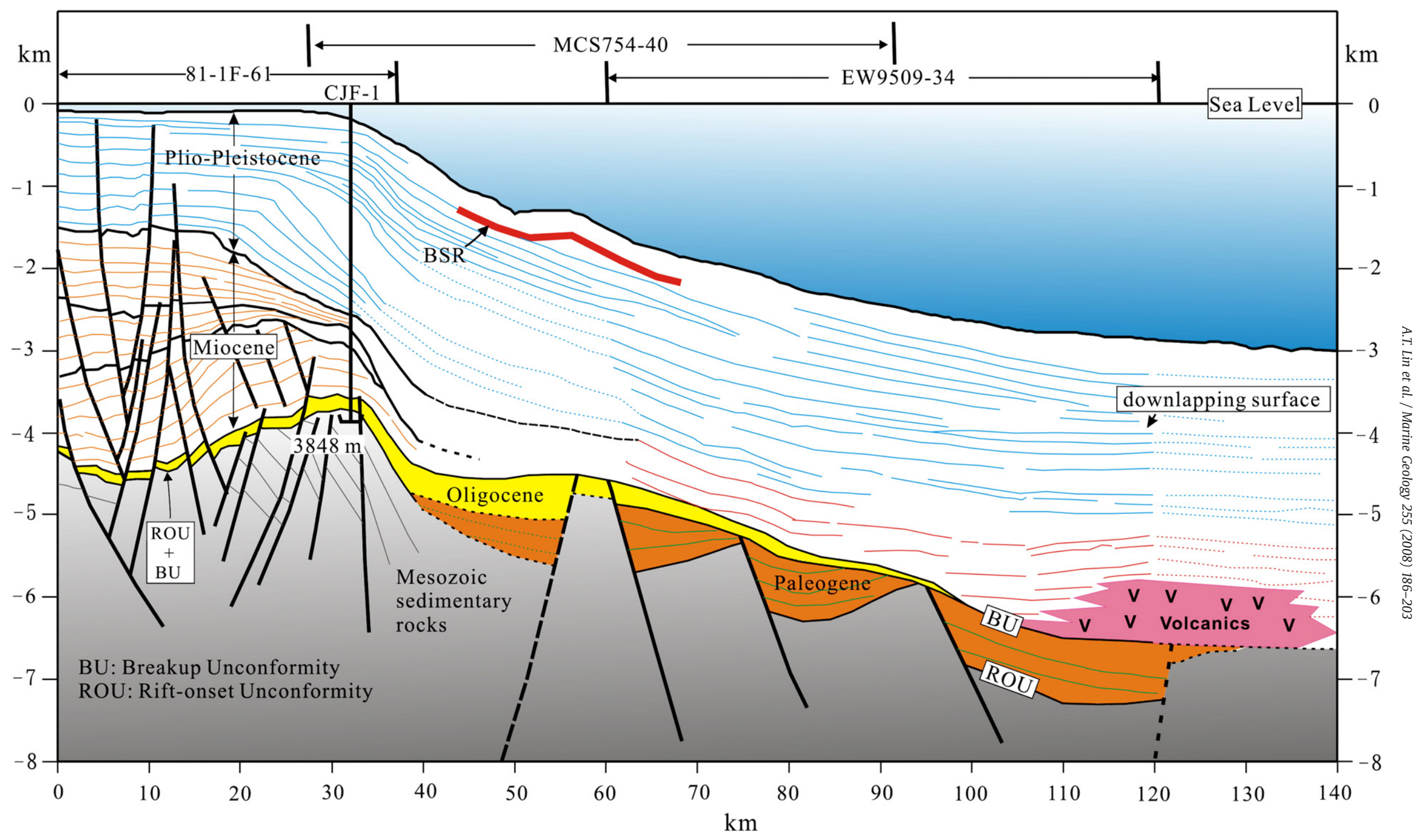

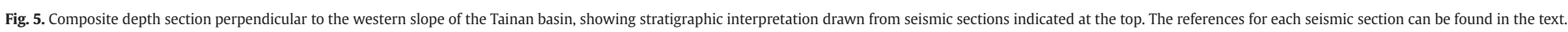

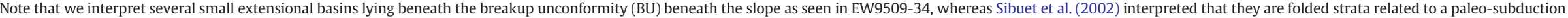
complex. Dashed lines are inferred features where seismic image is not available. 

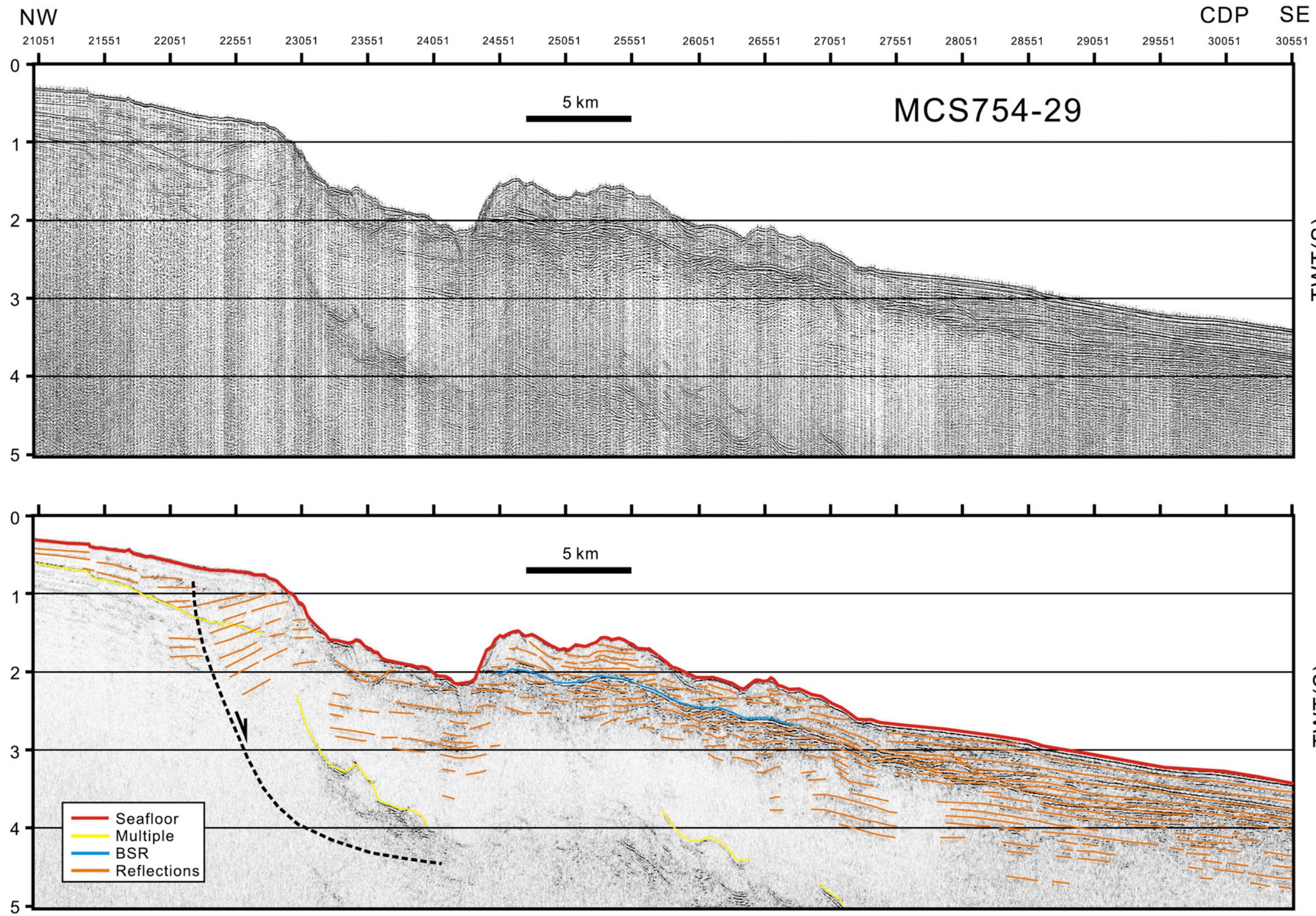

Fig. 6. Seismic section MCS754-29 running perpendicular to the Tainan slope (see Fig. 2 for location). (Upper) uninterpreted section. (Lower) line drawing interpretation. A normal fault with shelfward-tilted hangingwall strata is evident near the shelf break. The rotated hangingwall strata are then truncated beneath the upper slope as seen in between cdp 22,250 and 23,200. The map distribution of this normal fault is shown on Fig. 2 . 


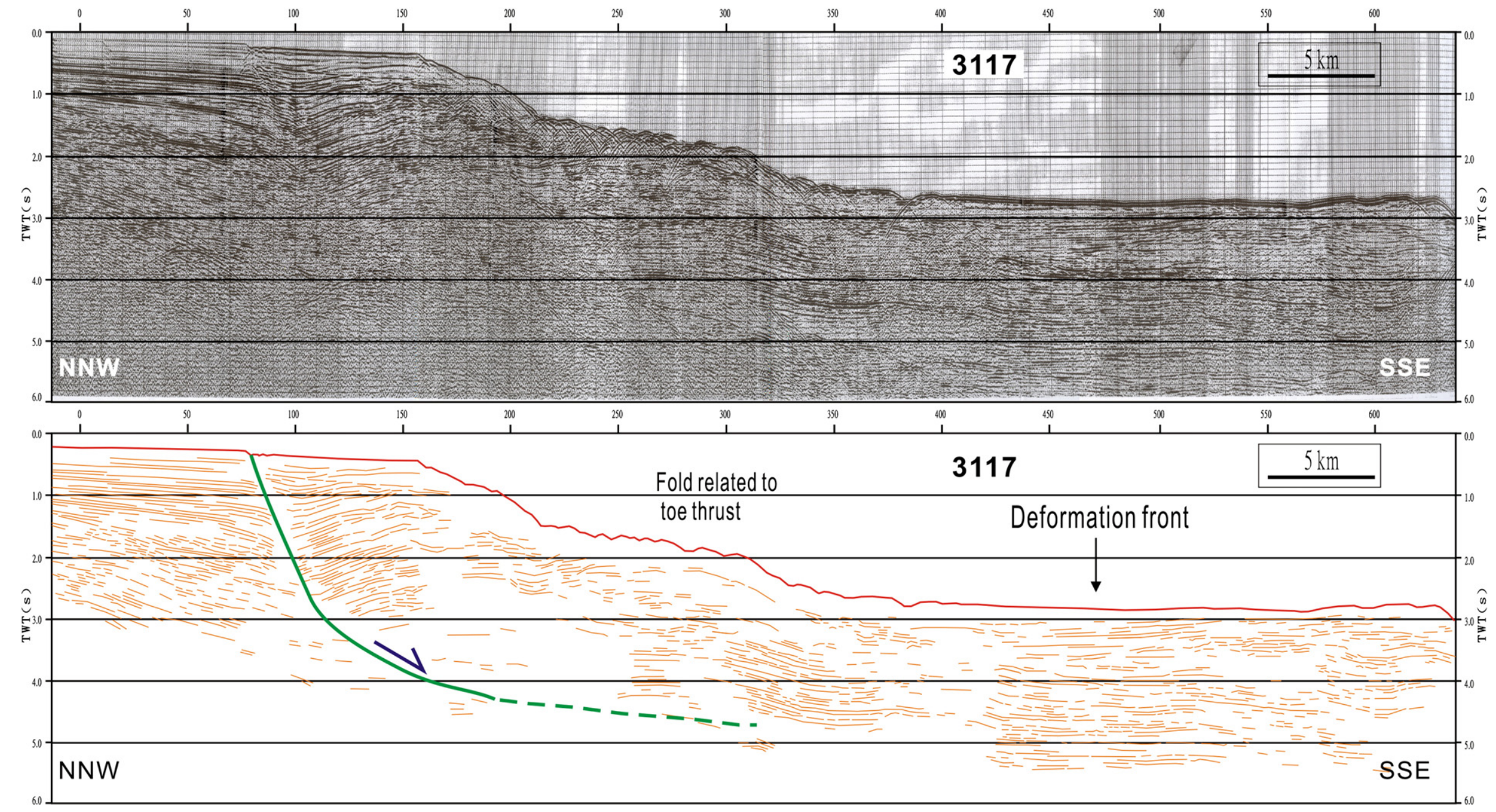

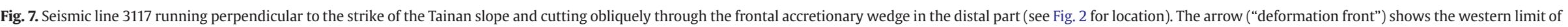

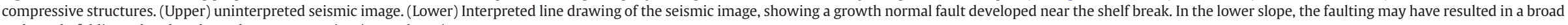
and gentle folding related to downslope compression (a toe thrust). 


\section{Topography and structures in the accretionary wedge}

\subsection{Orogenic topography, fold/thrust geometries and map patterns}

The submarine accretionary wedge off SW Taiwan is characterized by a narrow $(<20 \mathrm{~km})$ and smooth shelf (the Kaoping shelf, Yu and Chiang, 1997), and a broad ( $100 \mathrm{~km})$, rugged slope (the Kaoping slope) with a series of linear topographic ridges and troughs, extending from $\sim 200 \mathrm{~m}$ to $3000 \mathrm{~m}$ in water depth (Figs. 2 and 3). South of $\sim 22^{\circ} \mathrm{N}$, the accretionary wedge is overriding the SCS slope, which steepens from less than $1^{\circ}$ south of $22^{\circ} \mathrm{N}$ to $5^{\circ}$ in the north.

The accretionary wedge is divided by Reed et al. (1992) into lower and upper slope domains south of $22^{\circ} 10^{\prime} \mathrm{N}$, which can be followed north into our study area. The lower-slope domain can be further divided into frontal and rear segments according to our newly defined structures. The frontal segment is dominated by discrete folds with blind thrusts, and the rear segment by imbricate thrust systems with common occurrences of emergent thrusts in the area that shows high frontal curvature (i.e. near $22^{\circ} 10^{\prime} \mathrm{N}$, Fig. 3). The upper slope domain is dominated by mud diapirs that are usually buried by recent mud layers (Sun and Liu, 1993; Chuang, 2006).

Judging from the pronounced bathymetric expressions the structures of the accretionary wedge may well be very active (Fig. 3 ). This is particularly obvious in the lower-slope domain, where fault-related folds or upthrown thrust sheets form ridges, and synclines form troughs and piggyback basins. In the upper-slope domain, the tectonic morphology is less clear, as anticlinal ridges become progressively masked by hemipelagic sediments. Owing to the limited data coverage, the structures of the upper slope are adapted mainly from Chuang (2006) and Sun and Liu (1993), and will not be further addressed in this paper.

We learn from Fig. 3 that the apparently continuous bathymetric ridges do not correspond to a single anticline or thrust structure. Rather, for each bathymetric ridge, it consists of series of short and parallel anticlines and thrusts with similar senses of motions as revealed, for the first time, from the dense coverage of seismic data. More specifically, most of the geological structures are arranged in a relay pattern; as one fault dies out along strike, its displacement is transferred to a neighboring fault. An individual fault-related fold reaches its greatest amplitude, as manifested by the highest seafloor ridge-crest relief, and loses amplitude (and hence seafloor relief) toward the lateral tips of the fault, producing plunging anticlines. We herein termed this fold/fault array in each deformation unit a relay fault array.

For ease of discussion and to provide an index for particular geological structures, we name the subsurface structures in the lower-
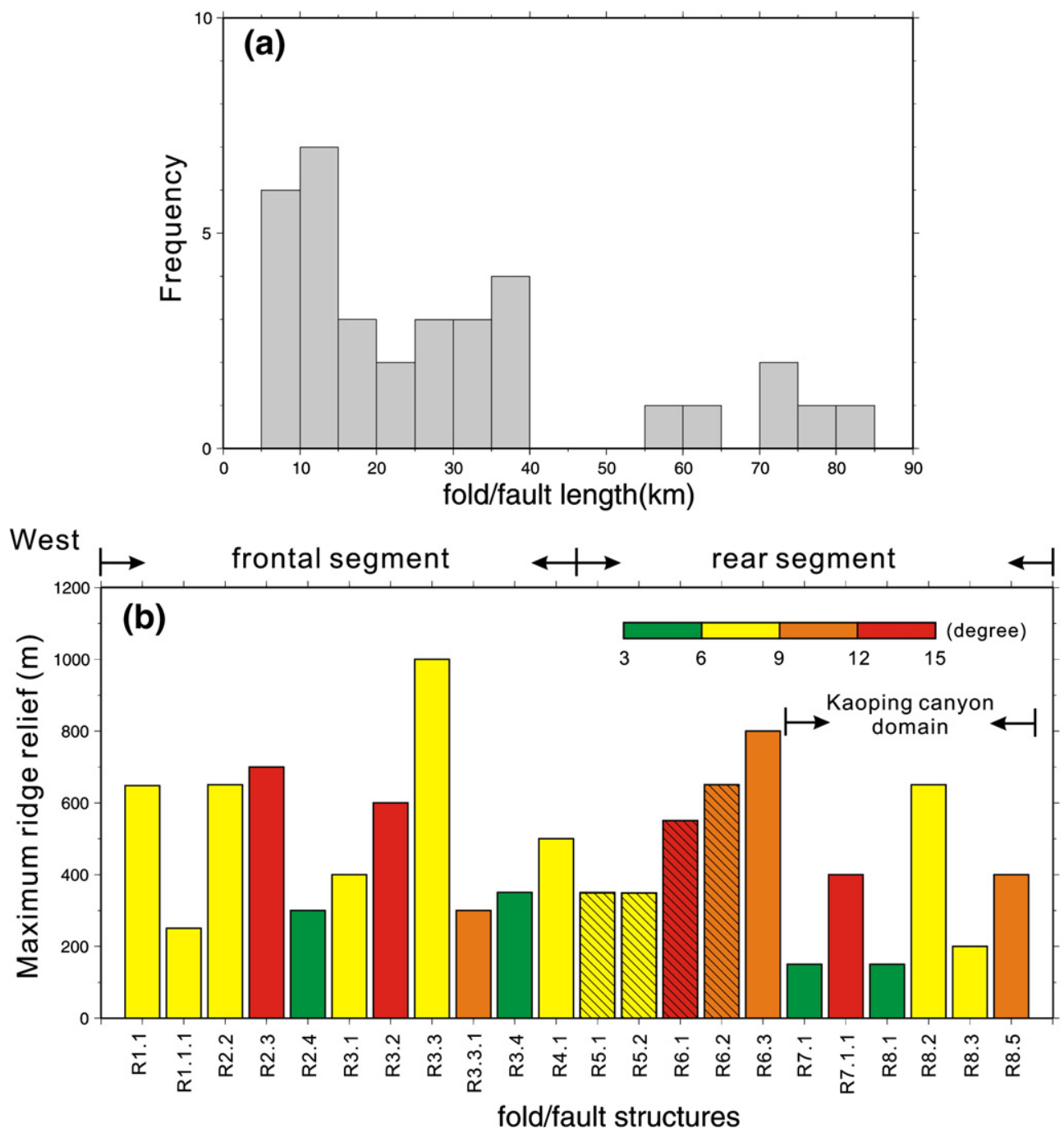

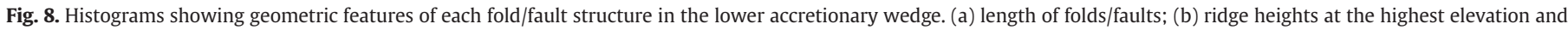

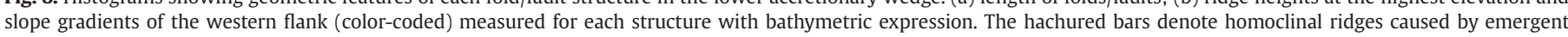
thrusting. 

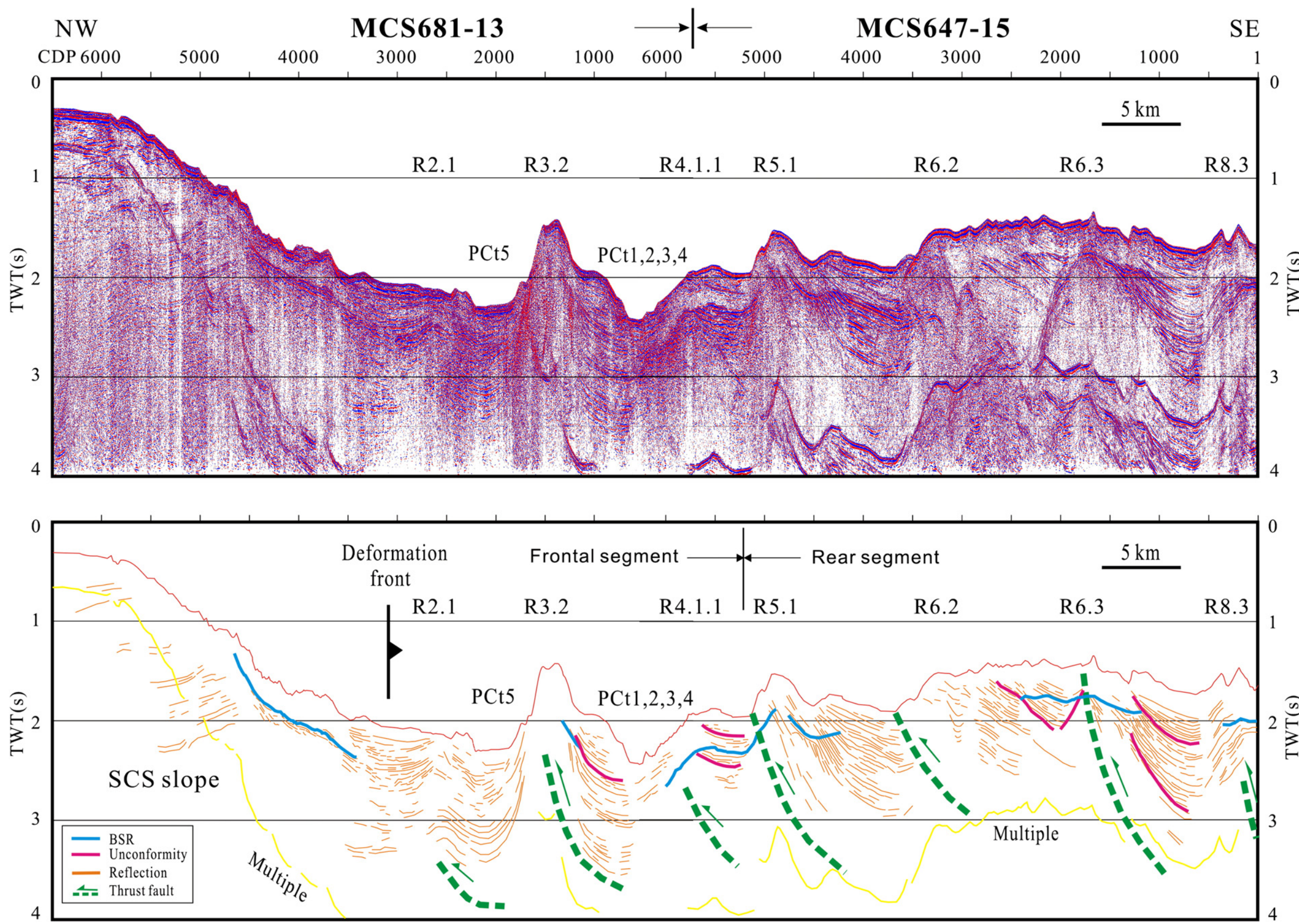

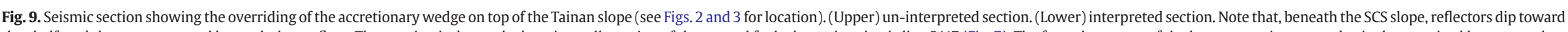

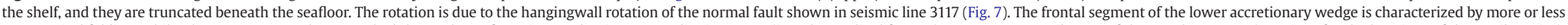

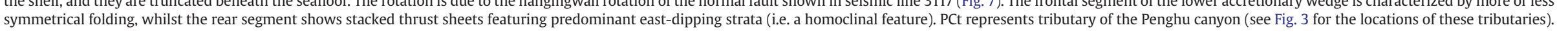


slope domain with the letter $\mathrm{R}$ followed by two or three digits, each separated from the others by a dot, for example, structure R3.3.1. The first digit indicates the number of a major contractional unit corresponding to the bathymetric ridges counting sequentially from the deformation front in an arcward direction. The second digit denotes the relay structures lying in the same deformation unit along strike, with smaller numbers in the north. The third digit, if present, is a subsidiary structure that occurs alongside and parallel to a nearby major structure indexed by the preceding letter and digit. We recognized 8 deformation units (R1 to R8) in the lower slope; each deformation unit is characterized by an array of faults/folds. Among them, R1 to R4 units of deformation correspond to structures A to D, respectively, mentioned by Liu et al. (1997). Additionally, structures of R6.1-R6.2 at the locations with their highest seafloor ridge-crest relief were collectively coined "Good Weather Ridge" by Lin et al. (2006). Notice that our naming convention for the geological structures off SW Taiwan is ad hoc and is only meant to clarify discussion of tectonic features in the study area.

The deformation front marks the initial point where the sediments have been deformed by contraction. In our study area, the frontal contractional structure is usually an anticline. We place the deformation front at the lowest and flat west limb of the frontal anticline to delineate the place where the accretionary wedge begins to overthrust the China continental slope. North of $\sim 22^{\circ} 10^{\prime} \mathrm{N}$, the strike of the deformation front turns at the upper continental slope of the SCS and does not follow a simple structure. Rather, it marks the boundary where a series of $\mathrm{N}-\mathrm{S}$ trending and en-echelon-arranged folds sequentially terminates against the continental slope as envisaged by Liu et al. (2004). The sharp NE deflection clearly defines the place where the deformation front impinges upon the upper SCS slope.

Our detailed mapping of the subsurface structures together with high-resolution seafloor imagery allow us to comment on the geometrical character of structures in the frontal accretionary wedge. Fig. 8 shows some geometric characteristics (i.e., length of folds, heights and slope gradients of structural ridges) of the contractional structures in the study area. The fold/fault length spans from $\sim 80 \mathrm{~km}$ to less than $10 \mathrm{~km}$ (Fig. 8a). Structures R1.1, R3.3, R5.1, R5.2, R6.1 and R6.3 are among the laterally extensive structures in the lower-slope domain, with structural lengths on the order of $60 \mathrm{~km}$ or more. The structures that are no the order of $<15 \mathrm{~km}$ long are subsidiary structures within major structural belts. These short structures are commonly less active than the major structures as evidenced by lower fold amplitudes.

Ridge-crest shape is asymmetrical in profile with steeper western slopes and gentler eastern flanks (Figs. 9-11), consistent with subsurface fold profiles. The asymmetrical profile is interpreted to result from west-vergent thrust kinematics. The fold amplitude may therefore serve as an indirect indicator for the competing effects between rates of tectonic uplift and sediment deposition similar to cases reported by Burbank and Verges (1994). If the rate of sediment deposition is higher than that of fold uplift, the fold structures tend to be buried by sediments, leaving features of subdued bathymetric ridges or no corresponding bathymetric expression of folds. By contrast, if the rate of fold uplift is higher than that of sedimentation, pronounced bathymetric ridges may result. In this sense, for each structure with corresponding surface expression, we selected its highest elevation along strike with respect to the neighboring troughs. Because channel incision increases the height of ridge crest, we measure the local height of ridge crest where no channel incision has occurred to the west of the ridge. We plotted the ridge height for each structure as shown in Fig. 8b.

Fig. 8b shows that the high crestal elevation is commonly associated with homoclinal ridges (thin dashed lines in Fig. 3 or hachured bars shown in Fig. 8b) formed by emergent thrusting in the rear segment as well as associated with anticlinal ridges in the frontal segment. Interestingly, those high-relief structural ridges occur particularly near the SCS slope (Fig. 3), indicating that the above two areas are associated with higher rate of fold/fault uplift than that of sedimentation. There is a systematic increase in ridge height northward along strike toward the SCS slope (Fig. 3). We interpret that the increase in fold/ridge amplitude in the vicinity of the SCS slope results from a higher level of tectonic stress there because of the buttressing effect of the ramping SCS slope that partly impedes the advance of the frontal orogenic wedge.

Close to the major sediment source, the island of Taiwan, structures R7.1-R8.5 show more subdued crestal heights, marked as Kaoping canyon domain in Fig. 8b (see also Fig. 3). We interpret that the subdued relief of the bathymetric ridges cored by folds near Taiwan is due to higher rates of sedimentation here than in the distal slope area, leaving a more smoothed topography. Huh et al. (2008) recently showed that sedimentation rates are higher near the coast and lower toward the distal slope. An alternative hypothesis for the subdued crestal heights of ridge R7-R8 is that these two ridges might have experienced more intense deformation over time than younger ridges (R1-R3) so that some segments coalesced, resulting in a smoother topography.

Fig. 8b also shows the slope gradient (in color) in the western flanks of the structural ridges in order to gain a better understanding of the local slope gradients associated with tectonic structures. It shows that the gradient of the local slope may reach up to $15^{\circ}$ (in red color) within a regional gradient of $\sim 1.5^{\circ}$ for the lower slope. The relatively steep local slopes associated with structural ridges and channel incision suggest that mass movements and gravity tectonics may be prevalent around the areas with steep slopes. Indeed, we have noted one normal fault, probably related to gravity tectonics, alongside and to the east of structure R4.1 as seen in Fig. 3.

\subsection{Styles of folding and thrusting}

In the lower accretionary wedge off SW Taiwan, a series of anticlines cored by blind thrusts have formed in response to sediment accretion in the frontal accretion zone. As the structure develops (that is, looking in an arcward direction), the thrust may breach the seafloor, producing a series of thrust imbricates and representing a zone of more advanced development of thrust belt. In the following, we provide descriptive information on the structures in the lower accretionary wedge, using a series of MCS profiles perpendicular to the fault trend as examples (Figs. 9-11).

\subsubsection{The frontal segment of the lower-slope domain}

The frontal segment of the lower slope comprises four structure belts (Fig. 3): R1 (with structures R1.1, R1.1.1, R1.1.2), R2 (R2.1, R2.2, R2.3, R2.4), R3 (R3.1, R3.2, R3.2.1, R3.3, R3.3.1, R3.4), and R4 (R4.1, R4.1.1). Structural belts R1 to R3 extend regionally in strike whereas R4 is developed only in the northeastern corner, sitting on top of the SCS slope incorporated in the accretionary wedge. Structure belt R4 consists of R4.1 and R4.1.1 with a prominent normal fault occurring at the east limb of the R4.1 anticline and along the steep wall $\left(\sim 13^{\circ}\right)$ of the Penghu Canyon (Fig. 3). The R4 deformed unit is a wedge-shaped unit in map view, which is sandwiched between the R3 and R5 belts north of $\sim 22^{\circ} 10^{\prime} \mathrm{N}$. South of $\sim 22^{\circ} 10^{\prime} \mathrm{N}$ the R4 belt disappears, and the R3 and R5 belts run closely sub-parallel to each other. This structural configuration leads to a significant bend along strike of the R5 structure at $\sim 22^{\circ} 10^{\prime} \mathrm{N}$ (Fig. 3). The significant westward swing of the R5 structure at $\sim 22^{\circ} 10^{\prime} \mathrm{N}$ also results in the fault breaching the seafloor, forming a successive emergent thrusts (i.e. R5.1 and R5.2, Fig. 3) with hangingwall strata dipping monoclinally arcward (Fig. 9). If the uniformly dipping stratal sequence in the hangingwall is expressed as a topographic ridge we name it a homoclinal ridge. The successive emergent thrusts (i.e., R5.1 and R5.2 structures, northern part of the R6.1 structure) are distinct, and they are very different from the thrust-cored anticlines seen in the R1 to R4 belts to the west. We 

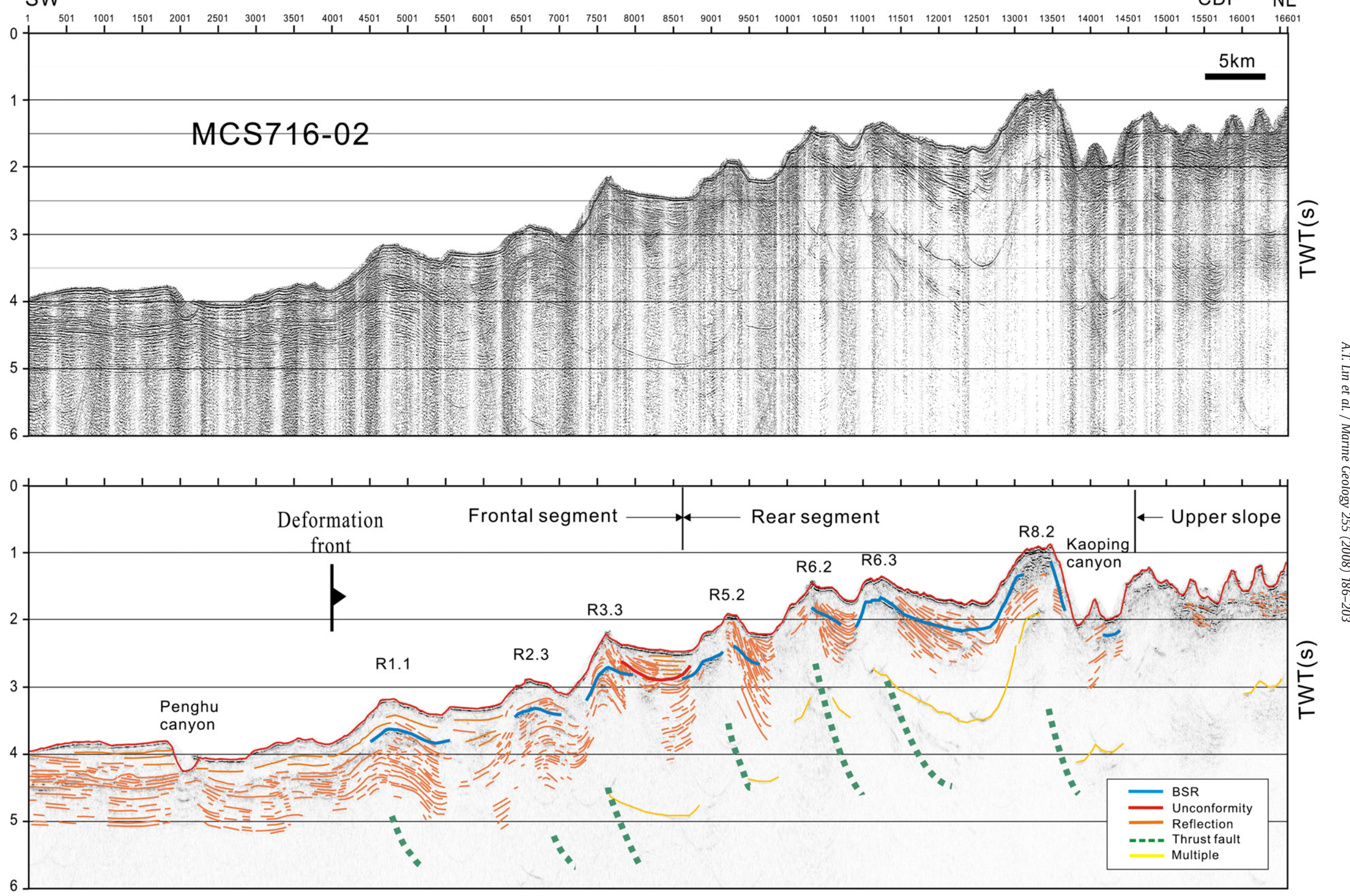

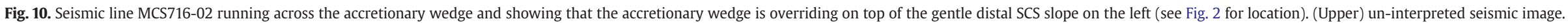

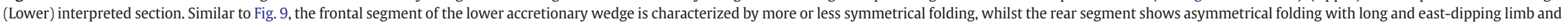
short west limbs. 

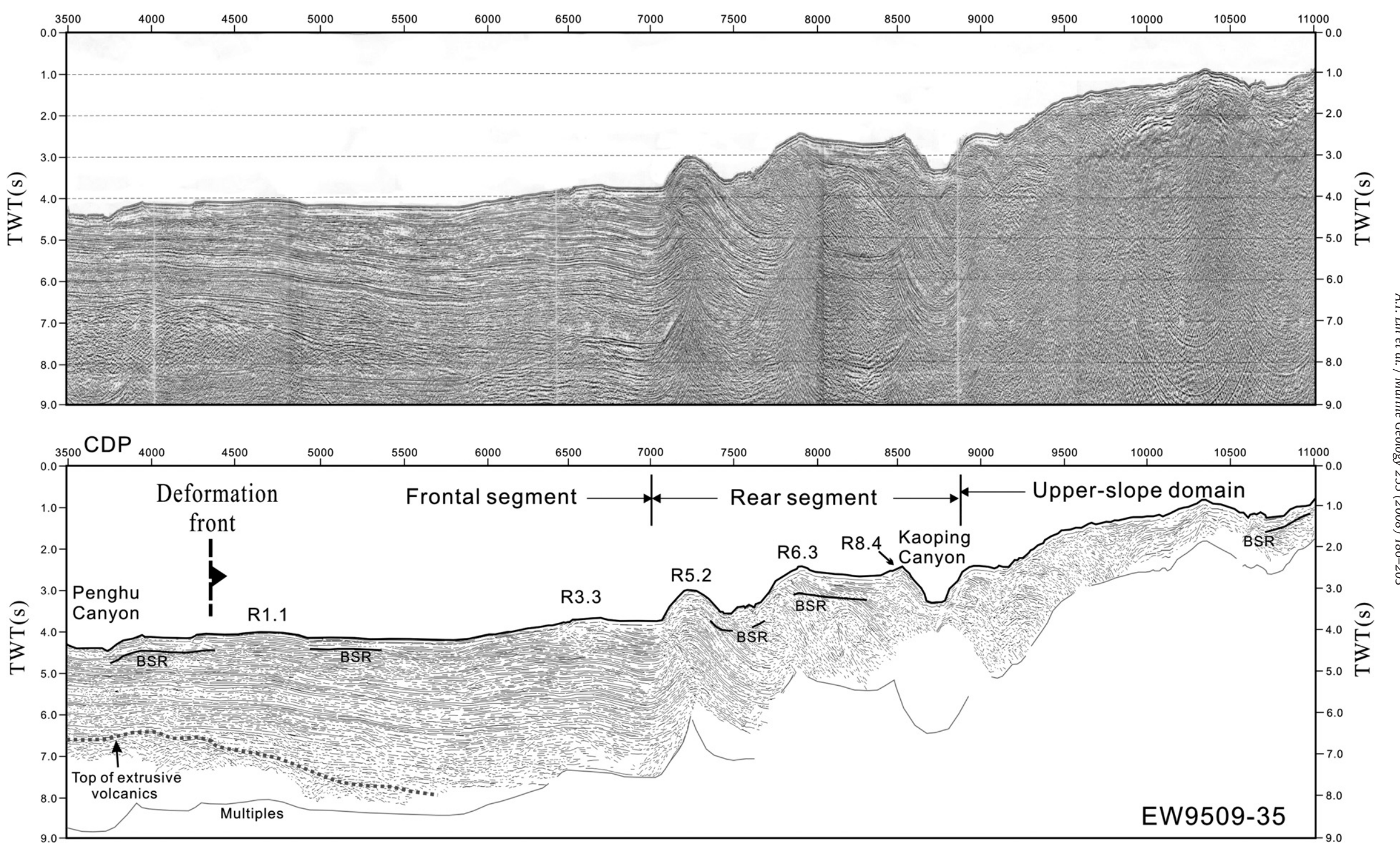

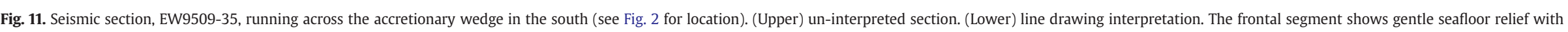
slightly deformed reflectors traceable to fold structures of R1.1 and R3.3 to the north. 
therefore use these emergent thrusts and their lateral continuation as the boundary separating the frontal and rear segments of the lowerslope domain (i.e. the thick dashed line in Figs. 2 and 3).

Structures in the frontal segment are predominant west-vergent folds with their west limbs slightly steeper than the east limbs. Seismic reflections are seen from both the frontal and back limbs of folds (e.g., Figs. 9-11). We interpret those folds to have formed due to slip along blind thrust faults, which interact with but do not break the seafloor because the faulting does not seem to cut through shallow strata. However, in a few places, the limbs of anticlines seem to be breached by faulting with limited offset. Almost all the folds in the frontal segments are active folds because they are mirrored in surface forms of linear ridges, except those of the R1.1.2, R3.2.1 and R4.1.1 structures, which are inactive folds as they are buried by flat-lying sediments and do not present corresponding bathymetric expression.

In addition to the predominant west-vergent anticlines, there are a few limited occurrences of east-vergent anticlines caused by back thrusting on the trailing side of a bathymetric ridge, or doubly-vergent anticlines owing to simultaneously forward and back thrusting beneath the same bathymetric ridge as seen in R3.2. There are also a few occurrences of active normal faults (Fig. 3), cutting through the seafloor due to locally steep topographic gradients, especially near the drainage of submarine canyons.

In a few places, subsidiary folds occur alongside and parallel to major structures, such as the structure labeled R3.3.1 in Fig. 3. The anticlinal ridges in the frontal segment commonly lack surface erosion as indicated by the parallelism of seafloor reflections with underlying stratal reflections (see the reflections of structures R1.1, R2.3, and R3.3 in Fig. 10). Areas of major erosion occur only in the reaches of submarine canyons. In between topographic ridges, the synclinal troughs are partly filled with sediments, comprising growth strata. The syntectonic stratal surfaces of growth strata are fanning outward, forming an overlap feature with beds progressively thinning toward the fold crest and decreasing in dip upward. The overlap feature indicates that the rate of structural uplift is less than that of sediment accumulation (Burbank and Verges, 1994). In a few places, the fanning growth strata are bounded at their base by an onlapping unconformity (red lines shown in Figs. 9 and 10). Growth strata as well as onlapping unconformity in the hangingwall and footwall of thrust faults and across anticlinal ridges indicate growth of the accretionary wedge. Most of the stratal surfaces of the growth strata in the frontal segment are more or less parallel to the bed dip of local structures with one exception. Fig. 10 shows that at the trough east of structure R3.3, a tapering and slightly eastward-dipping sediment wedge (maximum thickness $\sim 0.8 \mathrm{~s}$ ) onlap toward the east flank of R3.3. The stratal configuration for a slightly-tilted sediment packet draping over the flank of a more steeply dipping anticline along an onlapping unconformity indicates that the sediment packet was accumulated after the R3.3 anticline first initiated. A similar sediment wedge is absent in the west flank of structure R3.3, and the tapering sediment packet is contained only along the east flank of structure R3.3 and to the south of EW9509-33 seismic profile as shown in Fig. 2. These features prompt us to interpret this sediment wedge to have accumulated during a period when the paleo-Penghu Canyon was confined between structure ridges of R3.3 and R5.2.

\subsubsection{The rear segment of lower-slope domain}

The rear segment represents a zone of more advanced development of thrust belts than the frontal segment. The rear segment typically shows west-vergent and asymmetric fold profiles with long and planar backlimbs versus short forelimbs (Figs. 9-11). The west limb of each fold is characterized by poor seismic expression, probably related to steep stratal dip, while on backlimbs, there is usually a significant stratigraphic section deposited that shows evidence of limb rotation during fold growth. The growth strata are commonly bounded by an east-dipping onlapping unconformity at their base.
Unlike in the frontal segment, multiple packets of growth strata and their basal bounding unconformity are commonly stacked in the long backlimbs, indicating episodic thrust activities and prolonged history of deformation in the rear segment.

In a few structures, the forelimb is absent or very narrow in profile, and the backlimb is steeper beneath the bathymetric ridge with its stratal dip decreasing toward the synclinal trough, indicating that the thrusts have broken the seafloor. These emergent thrusts have upthrown the hangingwall strata to form homoclinal ridges (shown as dashed lines in Fig. 3) with underlying strata monotonously dipping arcward with a steeper cliff on the west and a gentle dip on back slopes. The asymmetric ridge profile results from tilting of the hangingwall strata and differential erosion. Alongside the homoclinal ridges, the emergent thrusts are depicted by barbed black lines in the rear segment (Fig. 3). In the west limb of the homoclines, the arcwarddipping strata are truncated beneath the seafloor, suggesting erosion in the west limb of homoclines (see, for examples, R5.1 and R6.2 structures shown in Fig. 9 or R6.3 shown in Fig. 11). The hangingwall tilting of strata has exposed once-deeply buried rock on the seafloor, suggesting that the truncated strata in the west limb are likely to be lithified and therefore more resistant for erosion, resulting in steeper slopes. Indeed, Jiang et al. (2006) reported that a few sediment samples, recovered from the seafloor at the homoclinal ridges, show lower porosity (15-40\%) and higher density (up to $2.2 \mathrm{~g} \mathrm{~cm}^{-3}$, termed hereafter hard muds) among otherwise "normal" samples, recovered elsewhere in the Kaoping slope. The "normal" samples show porosity of about $60 \%$ and density in the range of $1.6-2.0 \mathrm{~g} \mathrm{~cm}^{-3}$, termed hereafter soft muds). If the hard muds recovered at the seafloor result from mechanical compaction, the range of the porosity of the hard mud indicates that their paleo-burial depths span from 300 to $3000 \mathrm{~m}$ according to the compaction curve for mudstone in the Tainan Basin (i.e., at FJ-1 well, Lin et al., 2003). The existence of hard mud and truncations of seismic reflectors beneath the seafloor indicate that once-deeply buried sediments were uplifted and subsequently eroded, leaving more compacted sediments on the seabed especially at the hangingwalls of the emergent thrusts.

The emergent thrusts form where the vertical faulting displacements are greatest. They, however, gradually become blind thrusts along strike in both lateral tips of the structure as the vertical faulting offsets decrease. Near the lateral fault tips, both the folds and related faults terminate, resulting in plunging anticlines. Fig. 3 also shows that the number of emergent thrusts is greatest near the bend of the thrust belt at $\sim 22^{\circ} 10^{\prime} \mathrm{N}$ and the number of emergent thrusts decreases both in the northward and southward directions. In the south of the rear segment, the seafloor relief becomes subdued because folds plunge southward and finally disappear near the reach of the Kaoping Canyon.

There is a change in structural style along strike at about $22^{\circ} \mathrm{N}$. North of $\sim 22^{\circ} \mathrm{N}$, the rear segment is a zone of stacked thrust sheets with minor or no intra-slope basins and stratal surfaces dip mostly arcward. We interpret this feature to result from more intense and advanced deformation toward the hinterland of the orogen. South of $22^{\circ} \mathrm{N}$, the rear segment is a zone of discrete folds/faults with intervening intra-slope basins and longer forelimbs. In the south of the rear segment and near the west bank of the Kaoping Canyon, two small-scale diapiric structures have developed (Fig. 3), perhaps due to rapid sedimentation.

From the structural information presented above, we interpret that the structural development in the lower-slope domain as follows. During the course of thrust belt development, the strata are folded by blind thrusts in the initial stage, forming a series of discrete belts of deformation, and each deformed unit may consist of short segments of folds arranged in a relay fashion along strike. As the thrust belt continues to develop, the short segments of structures may eventually link and coalesce to form major structures with greater vertical offsets showing features of emergent thrusts near the center of structures. 
The more intense internal shortening also leads to shorter fold/thrust spacing.

\section{Discussion}

The most prominent tectonic feature in the study area is the oblique upthrust of an orogenic wedge on top of a rifted continentalmargin slope. In such a setting, the preexisting crustal inhomogeneity and surface relief of the rifted continental margin may exert strong controls on the structural styles and the development of the overriding orogenic wedge. Our detailed mapping of the subsurface structures in both the rifted continental margin and the accretionary wedge therefore provides us with an opportunity to address this issue. In this section, we discuss the possible origin of the salient frontal belt of the SW Taiwan accretionary wedge (Tainan salient).

In a broader view, the Tainan salient lies between $\sim 23^{\circ} \mathrm{N}$ and $20^{\circ} \mathrm{N}$ where incipient arc-continent collision occurs. South of $\sim 20^{\circ} \mathrm{N}$, the accretionary wedge trends in a NNE-SSW direction and maintains a fairly constant width of about $80 \mathrm{~km}$ (Fig. 1). North of $20^{\circ} \mathrm{N}$, the deformation front gradually swings to the west and the accretionary wedge widens. Whilst the trends of the frontal folds and thrusts turn to a NNW-SSE direction, the boundary between the Hengchun Ridge and the North Luzon Trough (Lundberg et al., 1997) remains N-S. North of $22^{\circ} \mathrm{N}$, as the NNW-trending accretionary wedge starts to impinge upon the NE-trending continental slope, the structural grain swings back eastward and connects to the onshore fold-and-thrust belt of Taiwan (Liu et al., 1997, 2004; Huang et al., 2004; Teng et al., 2005). This results in the width of the accretionary wedge/orogenic belt narrowing northward from $180 \mathrm{~km}$ south of $22^{\circ} \mathrm{N}$ to about $90 \mathrm{~km}$ in central Taiwan at $23^{\circ} 30^{\prime} \mathrm{N}$ and east of the Penghu Platform (Fig. 1).

Salient and reentrant curvatures of the frontal boundary of accretionary wedges are seen in many accretionary prisms as well as in mountain belts such as in the Barbados accretionary prism (e.g., Soto et al., 2003), the Apennines (e.g., Corrado et al., 1998), and Cordillerian thrust belts from Alberta to Nevada (e.g., Boyer, 1995). Many authors have attributed these curvature to be related to (1) the basement relief of the rifted continental margin, (2) the thickness of pre-orogenic sediments (e.g., Boyer, 1995; Soto et al., 2003), and (3) variations of pre-orogenic seafloor topography leading to rheological change along strike (e.g., Corrado et al., 1998; Corredor et al., 2005).

In the Tainan salient, the maximum sediment thickness of $\sim 3.5 \mathrm{~s}$ lies at about $22^{\circ} \mathrm{N}$ beneath the SCS slope (i.e. see EW9509-45 shown in Fig. 6 of Sibuet et al., 2002) and sediment thickness decreases toward the south (Sibuet et al., 2002; Hsu et al., 2004) as well as toward the north (Lin et al., 2003) from this point. The location for thickest preorogenic sediments corresponds to the location the deformation front swings farthest westward.

In the distal slope off SW Taiwan region at where the Penghu and Formosa Canyons meet, sediment thickness reaches only about $2 \mathrm{~s}$ as shown in the ACT Profiles 108 and 110 reported by Sibuet et al. (2002). Farther south at $\sim 21.5^{\circ}$ and near the lower reach of the Kaoping Canyon, the thickness of the subducted sedimentary layer is around $\sim 0.5-1 \mathrm{~s}$ according to Reed et al. (1992). Stepping farther south at $\sim 21^{\circ}$, the thickness of subducted sediments decreases to $\sim 0.2-0.4 \mathrm{~s}$ as seen in the Fig. 2 of Deng et al. (2006). Finally, farther south near $20.5^{\circ}$, almost all the incoming sediments have been accreted to the accretionary wedge (e.g., section BB' of Reed et al., 1992). The southward decrease in the thickness of subducted sediments is consistent with the sediment isopach to the west of the deformation front as suggested by Sibuet et al. (2002).

The existence of preexisting seafloor topography has resulted in a change in structural styles along strike of the lower slope domain. In the north, the advance of thrust belt is impeded by the SCS slope. The deformation front of compressive structures in the northern salient has been guided by the strike of the northern rifted basinmargin, leading to a change in the strike of the folds to become more parallel to the strike of the SCS slope, and a successive termination of folds from south to north against and along strike of the SCS slope. Farther south, the thrust belt is overriding a more-orless flat-lying basin floor, resulting in a southward decrease in fold amplitudes.

The positive correlation between longitudinal sedimentary tapering and the thrust trace prompts us to suggest that pre-orogenic sediment thickness is the major control on the geometry of frontal belts, and the preexisting SCS slope in front of the advancing orogenic wedge has resulted in a more curved frontal belt and larger fold amplitudes where the orogenic wedge impinges upon the SCS slope.

\section{Conclusions}

Based on the analysis of a dense grid of multi-channel seismic data and aided by high-resolution seafloor imagery, we find that structures in the frontal accretionary wedge offshore SW Taiwan present the following structural characteristics: (1) the structures form a curved belt convex toward the foreland (i.e., a salient feature), interpreted to result from the variation of pre-orogenic sediment thickness along strike; (2) the lower slope is dominated by structural styles of folding and thrusting, whereas folding and thrusting in the upper slope is coupled with mud diapirism; (3) the frontal fold/thrust belts of the lower-slope domain consist of discrete and elongated bathymetric ridges cored by blind thrusts with seafloor topography tied to subsurface structures; (4) the rear segment of the lower-slope domain consists of imbricate thrust slices with seafloor morphology not corresponding well to the complex subsurface structures; (5) more advanced deformation of the rear segment occurs in the area where bending of the orogenic wedge in map view is significant (i.e., near $\sim 22^{\circ} 10^{\prime} \mathrm{N}$ ), leading to faults breaching the seafloor (i.e., emergent thrusts); (6) each individual frontal structure does not consist of one single fold or thrust, rather, it consists of short segments of folds and thrusts arranged in a relay pattern; (7) individual deformed units show greater structural and bathymetric relief northward as they approach the SCS continental slope; and (8) upon impinging on the NE-trending SCS slope, the Ntrending fold/thrust structure terminates against the slope as its strike bends slightly to NE, sub-parallel to the strike of the SCS slope.

The rifted continental margin in front of the advancing orogenic wedge develops a gravity-driven and active listric normal fault with an erosive slope. The gravity-driven tectonics in the SCS slope may partly result from the impingement and loading of the westerly encroaching accretionary wedge. In the western half of the Tainan SCS slope, normal aggrading and prograding clinoforms, especially near the upper slope, resume.

Our results suggest that pre-deformational crustal heterogeneity of the rifted margin in terms of pre-orogenic sediment thickness and seafloor morphology impart strong controls on the structural styles and the development of the overriding frontal orogenic wedge.

\section{Acknowledgements}

The authors sincerely thank the captain, crew and technicians aboard R/V Ocean Researcher I who helped to collect the seismic data during 2002-2005. Thoughtful reviews and comments received from Neil Lundberg, Jean-Claude Sibuet, Jean-Yves Collot have greatly improved the quality of this paper. The help from the co-editor in chief, David Piper, is highly appreciated. This research has been supported through grants from the Central Geological Survey, Ministry of Economics Affairs, Taiwan.

\section{References}

Bartek, L.R., Vail, P.R., Anderson, J.B., Emmet, P.A., Wu, S., 1991. Effect of Cenozoic ice sheet fluctuations in Antarctica on the stratigraphic signature of the Neogene. J. Geophys. Res. 96 (B4), 6753-6778.

Boyer, S.E., 1995. Sedimentary basin taper as a factor controlling the geometry and advance of thrust belts. Am. J. Sci. 295, 1220-1254. 
Burbank, D.W., Verges, J., 1994. Reconstruction of topography and related depositiona systems during active thrusting. J. Geophys. Res. 99, 20281-20297.

Cartwright, J.A., Lonergan, L., 1996. Volumetric contraction during the compaction of mudrocks: a mechanism for the development of regional-scale polygonal fault systems. Basin Res. 8, 183-193.

Cartwright, J., Dewhurst, D., 1998. Layer-bound compaction faults in fine-grained sediments. Geol. Soc. Amer. Bull. 110, 1242-1257.

Chang, C.-P., Angelier, J., Lee, T.-Q., Huang, C.-Y., 2003. From continental margin extension to collision orogen: structural development and tectonic rotation of the Hengchun peninsula, southern Taiwan. Tectonophysics 361, 61-82.

Chen, M.-L., 2006. Sediment Velocity Structures in the Taiwan Strait and the Coasta Plain of West Taiwan. MSc. Thesis, National Central University, Taiwan, 110 pp. (in Chinese).

Chen, H.-W., Wu, L.-C., Shea, K.-S., Ho, H.-C., 2001. Explanatory Text of the Geological Map of Taiwan: Kaohsiung, Sheet 61, scale 1:50,000 (second edition). Taipei, Centra Geological Survey, Republic of China. (in Chinese).

Chiang, C.-S., Yu, H.-S., 2006. Morphotectonics and incision of the Kaoping submarine canyon, SW Taiwan orogenic wedge. Geomorphology 80, 199-213.

Chiang, C.-S., Yu, H.-S., Chou, Y.-W., 2004. Characteristics of the wedge-top depozone of the southern Taiwan foreland basin system. Basin Res. 16, 65-78.

Chuang, H.-J., 2006. Distribution and Structural Relationships of Mud Diapirs offshore Southwestern Taiwan. Institute of Oceanography, National Taiwan University. 113 pp.

Corrado, S., Di Bucci, D., Naso, G., Faccenna, C., 1998. Influence of palaeogeography on thrust system geometries: an analogue modelling approach for the Abruzzi-Molise (Italy) case history. Tectonophysics 296, 437-453.

Corredor, F., Shaw, J.H., Bilotti, F., 2005. Structural styles in the deep-water fold and thrust belts of the Niger delta. Am. Assoc. Pet. Geol. Bull. 89 (6), 753-780.

Deng, H., Yan, P., Liu, H., Luo, W., 2006. Seismic data processing and the characterization of a gas hydrate bearing zone offshore of southwestern Taiwan. Terr. Atmos. Ocean. Sci. 17, 781-797.

Hsu, S.-K., Yeh, Y.-C., Doo, W.-B., Tsai, C.-H., 2004. New bathymetry and magnetic lineations identifications in the northernmost South China Sea and their tectonic implications. Mar. Geophys. Res. 25, 29-44.

Huh, C.-A., Lin, H.-L., Lin, S., Huang, Y.-W., 2008. Modern accumulation rates and budget of sediment off the Gaoping (Kaoping) River, SW Taiwan: A tidal and flood dominated depositional environment around a submarine canyon. Journal of Marine Systems. doi:10.1016/j.jmarsys.2007.07.009.

Huang, C.-Y., Wu, W.-Y., Chang, C.P., Tsao, S., Yuan, P.B., Lin, C.-W., Xia, K.-Y., 1997. Tectonic evolution of accretionary prism in the arc-continent collision terrane of Taiwan. Tectonophysics 281, 31-51.

Huang, S.-T., Yang, K.-M., Hung, J.-H., Wu, J.-C., Ting, H.-H., Mei, W.-W., Hsu, S.-H., Lee, M., 2004. Deformation front development at the northeast margin of the Tainan basin, Tainan-Kaohsiung area, Taiwan. Mar. Geophys. Res. 25, 139-156.

Jiang, W.-T., Chen, J.-C., Huang, B.-J., Chen, C.-J., Lee, Y.-T., Huang, P.-R., Lung, C.-C., Huang S.-W., 2006. Mineralogy and physical properties of cored sediments from the gas hydrate potential area of offshore southwestern Taiwan. Terr. Atmos. Ocean. Sci. 17, 981-1007.

Lacombe, O., Mouthereau, F., Angelier, J., Deffontaines, B., 2001. Structural, geodetic and seismological evidence for tectonic escape in SW Taiwan. Tectonophysics 333, 323-345.

Lee, C.-W., Chiou, T.-Y., Wu, Y.-L., 1991. Foraminiferal paleoecology and depositional model for the Oligocene of the Tainan basin. Bull. Explor. Prod., Taiwan CPC Corporation 14, 83-102.

Lee, T.-Y., Tang, C.-H., Ting, J.-S., Hsu, Y.-Y., 1993. Sequence stratigraphy of the Tainan Basin, offshore southwestern Taiwan. Pet. Geol. Taiwan 28, 119-158.

Li, C.-F., Zhou, Z., Li, J., Hao, H., Geng, J., 2007. Structures of the northeasternmost South China Sea continental margin and ocean basin: geophysical constraints and tectonic implications. Mar. Geophys. Res. 28, 59-79.

Lin, A.T., Watts, A.B., 2002. Origin of the West Taiwan Basin by orogenic loading and flexure of a rifted continental margin. J. Geophys. Res. 107 (B9), 2185. doi:10.1029/ 2001JB000669.

Lin, A.T., Watts, A.B., Hesselbo, S.P., 2003. Cenozoic stratigraphy and subsidence history of the South China Sea margin in the Taiwan region. Basin Res. 15 (4), 453-478.
Lin, S., Hsieh, W.-C., Lim, Y.-C., Yang, T.F., Liu, C.-S., Wang, Y., 2006. Methane migration and its influence on sulfate reduction in the Good Weather Ridge region, South China Sea continental margin sediments. Terr. Atmos. Ocean. Sci. 17, 883-902.

Liu, C.-S., Lundberg, N., Reed, D., Huang, I.-L., 1993. Morphological and seismic characteristics of the Kaoping submarine canyon. Mar. Geol. 111, 93-108.

Liu, C.-S., Huang, I.-L., Teng, L.S., 1997. Structural features off southwestern Taiwan. Mar. Geol. 137, 305-319.

Liu, C.-S., Liu, S.-Y., Lallemand, S., Lundberg, N., Reed, D.L., 1998. Digital elevation model offshore Taiwan and its tectonic implication. Terr. Atmos. Ocean. Sci. 9, 705-738.

Liu, C.-S., Deffontaines, B., Lu, C.-Y., Lallemand, S., 2004. Deformation patterns of an accretionary wedge in the transition zone from subduction to collision offshore southwestern Taiwan. Mar. Geophys. Res. 25, 123-137.

Liu, C.-S., Schnürle, P., Wang, Y., Chung, S.-H., Chen, S.-C., Hsiuan, T.-H., 2006. Distribution and characters of gas hydrate offshore of southwestern Taiwan. Terr. Atmos. Ocean. Sci. 17, 615-644.

Lundberg, N., Reed, D.L., Liu, C.-S., Lieske Jr., J., 1997. Forearc-basin closure and arc accretion in the submarine suture zone south of Taiwan. Tectonophysics 274, 5-23.

Reed, D.L., Lundberg N. Liu, C.-S., Kuo, B.-Y., 1992. Structural relations along the margins of the offshore Taiwan accretionary wedge: implications for accretion and crustal kinematics. Acta Geol. Taiwan. 30, 105-122.

Rowan, M.G., Peel, F.J., Vendeville, B.C., 2004. Gravity-driven fold belts on passive margins. In: McClay, K.R. (Ed.), Thrust Tectonics and Hydrocarbon Systems. AAPG Memoir, vol. 82, pp. 157-182.

Sibuet, J.C., Hsu, S.-K., Le Pichon, X., Le Formal, J.P., Reed, D., Moore, G., Liu, C.-S., 2002. East Asia plate tectonics since 15 Ma: constraints from the Taiwan region. Tectonophysics 344, 103-134

Soto, R., Storti, F., Casas, A.M., Faccenna, C., 2003. Influence of along-strike pre-orogenic sedimentary tapering on the internal architecture of experimental thrust wedges. Geol. Mag. 140 (3), 253-264.

Sun, S.-C., Liu, C.-S., 1993. Mud diapirs and submarine channel deposits in offshore Kaohsiung-Hengchun, southwest Taiwan. Pet. Geol. Taiwan 28, 1-14.

Sung, Q., 1991. Explanatory Text of the Geologic Map of Taiwan: Hengchun Peninsula, Sheets 69, 70, 72, scale 1:50,000. Taipei, Central Geological Survey, Republic of China. (in Chinese)

Tang, F.S., Oung, J.-N., Hsu, Y.-Y., Yang, C.-N., 1999. Elementary study of structural evolution in Tainan Basin in southwest Taiwan Strait. Pet. Geol. Taiwan 33, 125-149 (in Chinese).

Teng, L.S., Rau, R.-J., Lee, C.-T., Liu, C.-S., Chen, W.-S., 2005. Faulting in southwestern Taiwan. West. Pac. Earth Sci. 5, 97-128 (in Chinese).

Tsao, W.C.-Q., Chang, M.M., 1988. The study of petroleum potentiality of Oligocene sandstones in Tainan basin and its application. Min. Metall. 33 (1), 49-57 (in Chinese).

Tsao, W.C.-Q., Oung J--N., Yang C.-M., Lee, YW., Wang, M.-H, Uang, Y.-C., Tang, S.-L, 1992. Studies on hydrocarbon potential of Mesozoic formation in the Tainan basin, southwestern offshore Taiwan. Min. Metall. 36 (1), 32-45 (in Chinese).

Tzeng, J., Uang, Y.-C., Hsu, Y.-Y., Teng, L.S., 1996. Seismic stratigraphy of the Tainan Basin. Pet. Geol. Taiwan 30, 281-308 (in Chinese).

Wynn, R.B., Stow, D.A.V., 2002. Classification and characterization of deep-water sediment waves. Mar. Geol. 192, 7-22.

Yan, P., Deng, H., Liu, H., 2006. The geological structure and prospect of gas hydrate over the Dongsha Slope, South China Sea. Terr. Atmos. Ocean. Sci. 17, 645-658.

Yang, K.-M., Ting, H.-H., Yuan, J., 1991. Structural styles and tectonic modes of Neogene extensional tectonics in southwestern Taiwan: implications for hydrocarbon exploration. Pet. Geol. Taiwan 26, 1-31.

Yu, H.-S., Lu, J.-C., 1995. Development of the shale diapir-controlled Fangliao Canyon on the continental slope off southwestern Taiwan. J. SE Asian Earth Sci. 11 (4), 265-276.

Yu, H.-S., Chiang, C.-S., 1997. Kaoping Shelf: morphology and tectonic significance. J. Asian Earth Sci. 15, 9-18.

Yu, H.-S., Chang, J.-F., 2002. The Penghu submarine canyon off southwestern Taiwan: morphology and origin. Terr. Atmos. Ocean. Sci. 13, 547-562.

Yu, S.-B., Chen, H.-Y., Kuo, L.-C., 1997. Velocity field of GPS stations in the Taiwan area. Tectonophysics 274, 41-59. 